\title{
超高速鉄道走行時の構造物及び地盤の 振動に関する実測と予測
}

\author{
宇野 護 1 永長隆昭 $2 \cdot$ 藤野陽三 $3 \cdot$ 芦谷公稔 $4 \cdot$ 森川和彦 5 \\ 1フェロー 東海旅客鉄道(株) 中央新幹線推進本部（†108-8204 東京都港区港南2-1-85） \\ E-mail:m.uno@jr-central.co.jp \\ 2正会員 東海旅客鉄道(株) 中央新幹線推進本部（干108-8204 東京都港区港南2-1-85） \\ E-mail: t.nagaosa@jr-central.co.jp \\ 3フェロー 東京大学教授 工学系研究科社会基盤学専攻（ \\ E-mail: fujino@civil.t.u-tokyo.ac.jp \\ 4正会員 (公財)鉄道総合技術研究所＼cjkstart総務部（干108-8204 東京都国分寺市光町2-1-85） \\ E-mail: ashiya@rtri.or.jp
}

${ }^{5}$ (株)大崎総合研究所（†100-0011 東京都千代田区内幸町2-2-2）

E-mail: k.morikawa@ohsaki.co.jp

\begin{abstract}
本論文は，超高速鉄道における沿線地盤振動の特性を振動の発生・伝達の観点から把握し，予測モデル を構築して, 営業線で想定される条件における予測を行うものである. 実験線での走行試験結果から, 超 高速鉄道では車両による周期的な加振の影響に加えて, 高架橋の振動特性や地盤の特性が沿線地盤振動に 大きく寄与していることを明らかにした。ささらに，営業線で想定される地盤条件や，環境対策工を含めた 構造物条件を再現可能な3次元シミュレーション解析モデルを構築して振動レベルの予測を行い, 環境保 全目標值である新幹線振動の勧告值が営業線においても十分に達成可能であることを確認した.
\end{abstract}

Key Words :high-speed railway, ground vibration, girder bridges, field vibration measurement, test line, 3-D analysis, voxel model

\section{1. はじめに}

$500 \mathrm{~km} / \mathrm{h}$ の超高速で走行する超電導磁気浮上式鉄道 （以下，本論文においては「超高速鉄道」と略称 : なお 整備計画上の最高設計速度は505km/h） は我が国独自の 技術を駆使した新たな輸送機関として開発が着実に進め られ，2009年7月には技術開発全般に亘る総括的な技術 評価が国の「超電導磁気浮上式鉄道実用技術評価委員 会」により行われて, 超高速大量輸送システムとして運 用面も含めた実用化の技術の確立の見通しが得られてい るとの結論を得ている11)。一方，経済社会の大動脈であ る東海道新幹線は開業後47年を経過し，将来的な経年劣 化や大規模災害に対する抜本的な備えを考えなければな らない時期にきている．そのためこの役割を代替寸るバ イパスとして全国新幹線鉄道整備法に基づく中央新幹線 の整備計画が2011年5月に決定され，超高速鉄道を適用 した新線の建設手続きに着手したところである.
こうした鉄道の新線建設にあたっては，想定される輸 送需要を安全, 確実かつ効率的に満たすことのできる路 線の計画を行うのは勿論のこと，環境に与える影響を適 切に評価した上で必要な対策を実施することが重要であ り，特に沿線の騒音振動防止に対しては最大限の配慮が 必要である.

超高速鉄道の環境対策のうち沿線地盤振動については, 後藤らりにより測定結果の報告が行われており, 前述の 技術評価の中でも「車両が軽量でかつ土木構造物への荷 重が分散しているため小さいという特性を持っており, 特段の対策をせずとも『環境保全上緊急を要する新幹線 振動対策について（勧告）』 ${ }^{3}$ に準拠して設定した基準 值（案）が充分達成可能である」とされている1). しか しながら，計画路線の影響予測を適切に行うためには， 沿線における種々の構造物や地盤の条件に対応した地盤 振動の予測を行って実測值を補完することが望ましく， そのための手法を振動の発生・伝播特性を反映して構築 
することが必要である。

新幹線の沿線地盤振動については旧国鉄の時代から研 究が進められてきており，振動の発生・伝達に関する特 性が明らかにされている，例として吉岡4によるJR民営 化前後の膨大なデータの分析・考察や芦谷・吉岡5)及び 横山らのよる高速化時の特性把握の研究が挙げられる. また構造物の振動特性と沿線地盤振動との関連について, ラーメン高架橋を対象として，原ら7による高架橋端部 の付加的な振動とその低減策の研究や，吉田・関8にに る鉄道振動の高架橋健全度評価への活用の研究が進めら れている，一方，超高速鉄道は図-1に示す通り，浮上す る車両を既存鉄道の軌道に相当するガイドウェイ（側壁 及び走行路により構成される，以下，本論文において

「軌道部分」と呼ぶ）が支持・案内・推進しており，か つ高架橋の標準構造がこれまで新幹線であまり研究の対 象とされていない桁橋構造であるため, 振動の発生・伝 達機構が新幹線の場合とは異なり，沿線で観測される振 動特性にも影響を与えている可能性がある，超高速鉄道 の構造物振動の特性については，車両走行に伴う共振と いら観点から研究が進められた事例はある（例えば曾我 部ら $\left.{ }^{9)}\right)$ が，沿線地盤振動との関連を論じた研究は過去 に行われていない.

鉄道における振動レベルの予測に関しては，これまで 実測データを引用する例が多かった ${ }^{10)}$ が，近年では入 力及び伝播系をモデル化して予測する解析的手法や，実 測データと解析モデルを組合わせて予測する方法(例え ば吉岡 ${ }^{11)}$ による等価起振力法)の研究が進んできている. 超高速鉄道においても，土地利用や地盤特性の異なる 種々の地域を通過することや環境対策工として明かりフ 一ドを設置する場合もあることを考慮し，振動の発生・ 伝達機構を適切に反映したモデルを構築して沿線地盤振 動の予測・評価を進めていくことが望ましい.

そこで本論文は，実験線における測定結果に基づいて 超高速鉄道における沿線地盤振動の特性を振動の発生・ 伝達の観点から解明する. その上で現象の再現を可能と する数值計算モデルを構築して, 営業線で想定される 様々な構造物及び地盤条件における予測を行い，前述の 基準值（案）が十分に達成可能であることを検証する.

\section{2. 測定結果に基づく沿線地盤振動現象}

\section{(1) 測定条件}

車両走行時の振動の発生特性及び軌道部分から構造 物，沿線地盤にかけての伝達特性を把握するため，実験 線の2箇所の高架橋・橋梁において測定を実施した．対 象とした構造物の概要を図-2に示す.

A高架橋は実験線の標準形式である桁長37.8mのPRC箱 林で，施工基面までの高さは約23m，基礎は直接基礎と
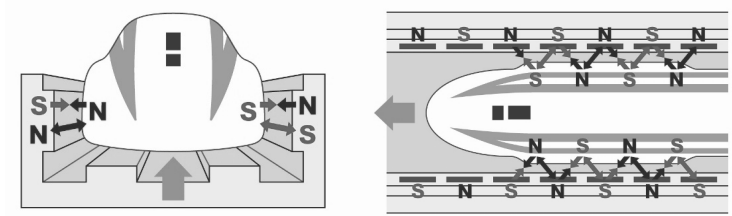

図-1＼cjkstart超高速鉄道の推進・浮上の原理
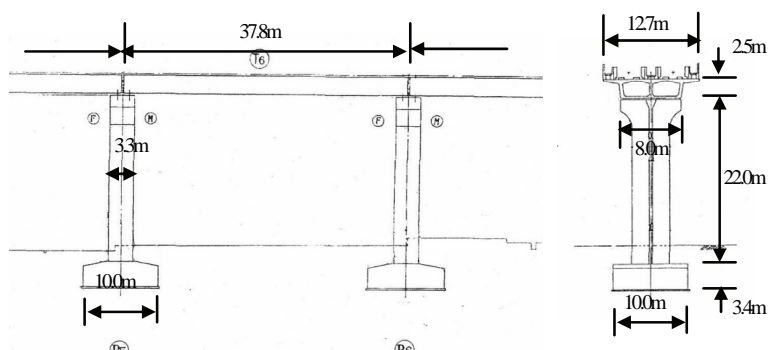

1) $A$ 高架橋
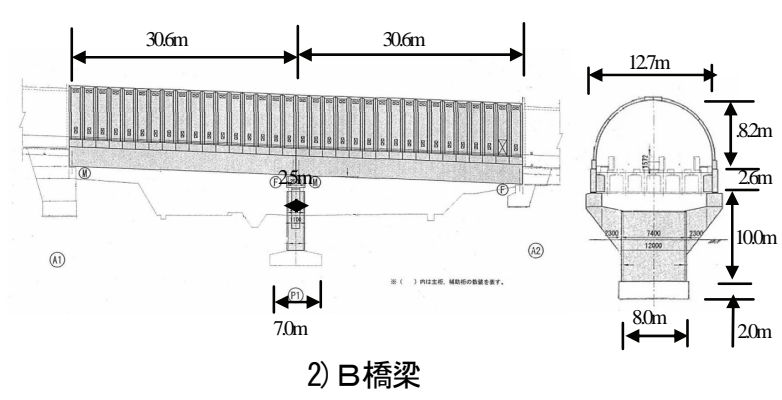

図-2 測定対象構造物の概要

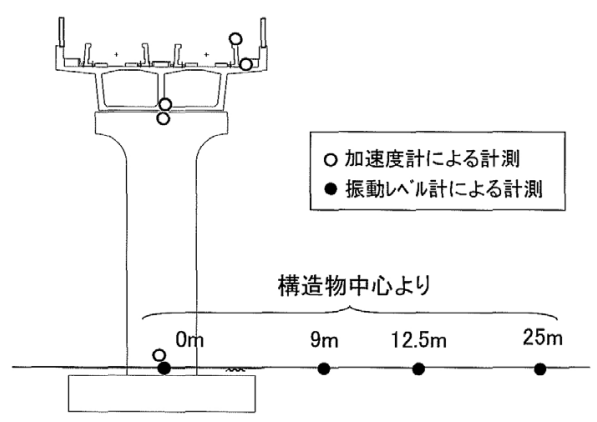

図-3 振動の測定位置

なっている，表層は厚さ3m, N值は4程度のローム層で 測定箇所付近では概ね水平に分布している，B橋梁は卜 ンネル間の短い谷地形の明り区間にある栴長 $30.6 \mathrm{~m} の$ PCT桁で，環境対策工として明かりフードを設置してい るのが特徴である。施工基面までの高さは約9m，基礎 は直接基礎である，表層地盤はシルト及び砂礫が主体の 互層で厚さは6m，N值は10程度である，それぞれの基礎 地盤のN值は50以上である。

構造物・地盤における具体的な測定位置を図-3に示す. 構造物内の振動伝達を計測するため, 桁の支点付近の同 一断面において，加速度計を側壁上部，側壁に接する高 架橋・橋梁のスラブ面と裏面, および橋脚の上・下部に 設置した. また周辺地盤の影響を把握するため, 振動レ 
ベル計を線路中心直下から距離を変えて配置した。

一方，車両は図-4に示寸4両編成の試験車両であり， 積車重量は先頭車両で約330kN, 中間車両で約200〜 220kNである，台車は連接台車であり，1台車が両側の 車体を支持している. 低速走行時はゴムタイヤにて走行 するが，1台車を2軸で支持するため，軸重は約110kNで あり新幹線（約450kNを2台車4軸で支持している）と同 程度である. 今回, 低速車輪走行時として $70 \sim 200 \mathrm{~km} / \mathrm{h}$, 高速浮上走行時として200〜 $500 \mathrm{~km} / \mathrm{h} の$ 速度で測定を行っ た. 測定は水平成分についても実施したが，水平成分に 比べて鉛直成分が卓越する（新幹線においても同様の傾 向がある ${ }^{4)}$ ) ことや，新幹線振動における測定・影響評 価の対象が鉛直成分のみであることを考慮し，鉛直成分 のみに着目して分析を進めることとした．さらに，本研 究は沿線地盤における振動レベルの予測・評価を最終的 な目的としており，周波数毎に定められた相対レスポン スに基づく感覚補正を行って振動レベル（オールパス (AP)振動レベル) が算出されることから，周波数毎の特 性を把握することが研究を進める上で極めて重要である. そこで, 本研究における計測結果は基本的に $1 / 3$ オク ーブバンドの振動レベルで分析・評価を実施することと した.

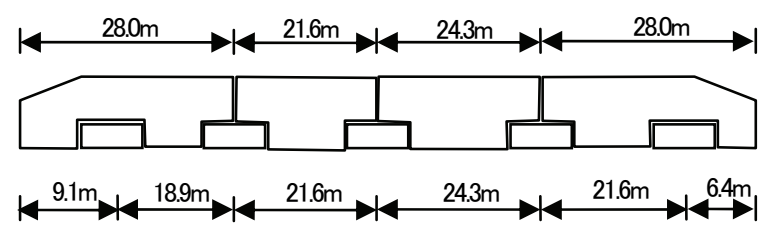

図-4 試験車両の概要

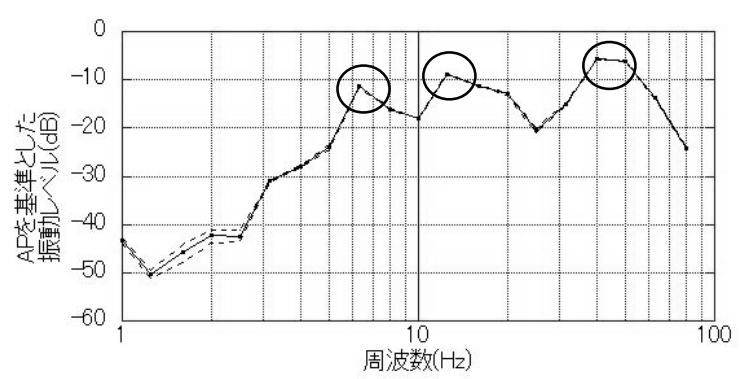

1) $A$ 高架橋

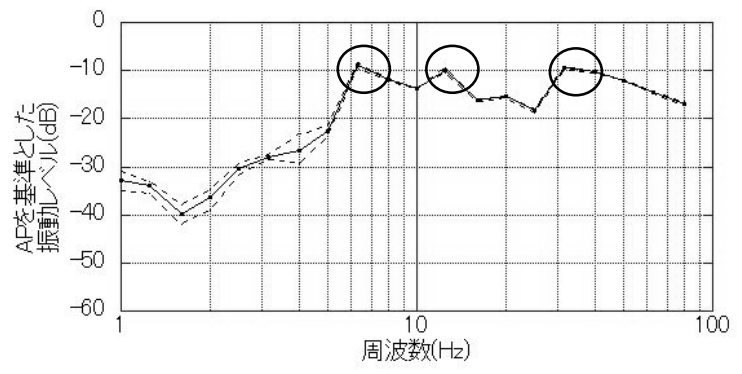

2) B橋梁

図-5 500km/h走行時の側壁上部における 1/3オクターブバンド振動レベル

\section{（2）軌道部分における振動発生特性}

最初に，軌道部分における振動の発生特性について 整理する. 図-5にA高架橋，B橋梁における $500 \mathrm{~km} / \mathrm{h}$ 走行 時の側壁上部1/3オクターブバンド振動レベル分析結果 を示す．なお本論文では，特に断りのない場合，各測定 位置の1/3オクターブバンドの振動レベルについて， AP の振動レベルを基準に正規化したうえで，表示している. グラフの点線は複数列車における測定值の最大と最小を 表しており，実線は測定值の平均（新幹線振動の測定評 価は算術平均で行うと規定されているため，ここでは算 術平均としている：以下同様）を表している. どちらの 場合も，6.3Hz，12.5Hzの成分にピークを有することが確 認される. また高周波数領域においては，A高架橋で40 〜 $50 \mathrm{~Hz}$ 前後の成分が卓越している一方, B橋梁では上記

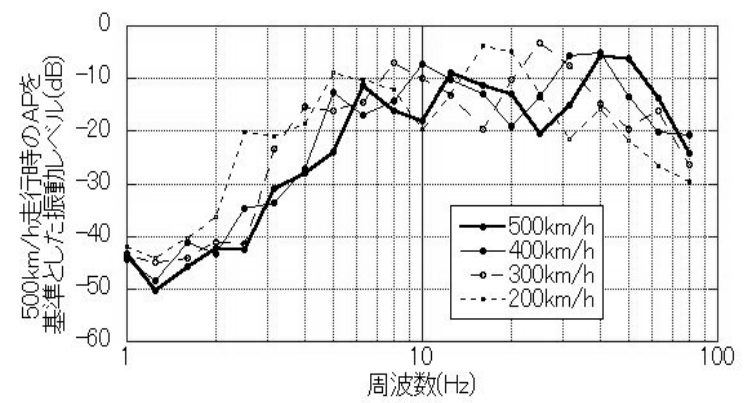

図-6Ａ高架橋の側壁上部における1/3オクターブバンド 振動レベルの速度による変化
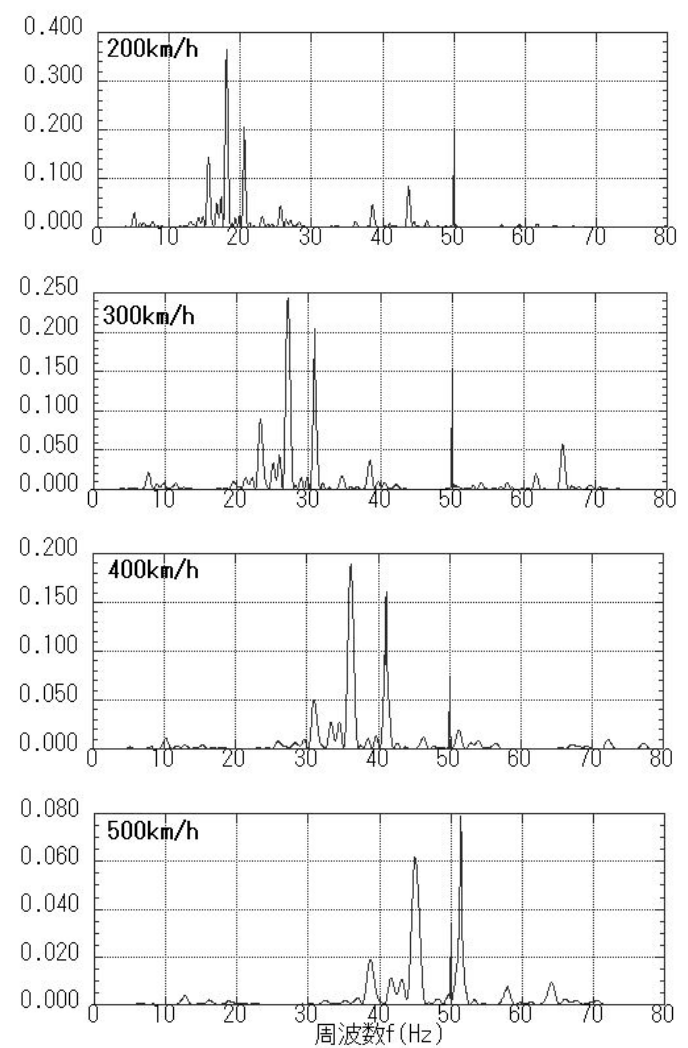

図-7Ａ高架橋の側壁上部における 振動の正規化パワースペクトル 
の他に31.5Hz付近の周波数成分が含まれている.

次に，ピークとなる周波数の要因を探るため，A高架 橋において1/3オクターブバンド振動レベルの速度によ る変化の状況を図-6に整理した. グラフは各速度におけ る複数列車の平均值を表している．200km/hの場合に見 られる2.5Hz，5Hz，16Hzのピークが速度が増すにつれて 高い周波数側 $(500 \mathrm{~km} / \mathrm{h}$ で $6.3 \mathrm{~Hz}, 12.5 \mathrm{~Hz}, 40 \mathrm{~Hz})$ に移動 していることが確認され，これらは速度に依存する成分 であることがわかる．B橋梁でも同様の傾向である．さ らに側壁上部における振動のパワースペクトル（分散に より正規化して表示 : 以下同様）を分析し，速度別に整 理すると図-7の通りとなり, 以下の特徵が確認される.

1) 個々の小さな波形のピークは，台車間隔（18.9m〜 24.3m）に起因する周波数の整数倍となっている.

2) 全体的に見た大きな波形のピークは2.7m前後の長さ に起因する周波数となっている.

このうち2)について, 走行速度とともにピーク周波数 が移動するのは，車両から軌道部分へ走行速度に応じた ある特定の間隔の繰り返し荷重が作用しているためと考 えられる. 図-6の500km/hの場合の6.3Hzは台車間隔（試 験車両における代表的間隔は21.6m） に依存していると 考えられる．また，12.5Hzと40〜 50Hzは $10.8 \mathrm{~m}$ と $2.7 \mathrm{~m}$ の間 隔に依存すると想定されるが，この間隔は超電導磁石の 極間隔1.35mの整数倍となっている. 同様の特性は新幹 線においても観測されている。横山らの)の研究によれば, 新幹線車両が200 350km/h程度で走行する場合, 超低域 (2〜 4Hz) , 低域 $(6.3 \sim 12.5 \mathrm{~Hz})$, 中域 $(20 \sim 40 \mathrm{~Hz})$, 高域 (40〜80Hz) にピークがあらわれ，そのうち明かり 区間では超低域〜中域が主体になるが，これらのピーク は台車の車軸間隔 $2.5 \mathrm{~m}$ との整数倍の台車間隔 $17.5 \mathrm{~m}$ 車両長 $25 \mathrm{~m}$ に依存する車軸の繰り返し加振に起因すると 考えられている. これらのことから，超高速鉄道の軌道 部分における振動の発生特性は, 新幹線と同様に車両の 超電導磁石の極間隔や台車間隔等で繰り返される荷重の 影響を受けるものと考えられる．ただし，A高架橋にお いては軌道部分の側壁の支持間隔も $2.7 \mathrm{~m}$ なっているた め, $500 \mathrm{~km} / \mathrm{h}$ 走行時の $40 \sim 50 \mathrm{~Hz}$ のピークは地上側設備が 順次繰り返し加振される影響も考えられる. B橋梁にお いても同様の傾向が確認されるが，高周波域で確認され た31.5Hzのピークについては，B橋梁で側壁の一部に 6.3mとA高架橋に比べて長い支持間隔の箇所があり，こ の間を通過する際の規則的な加振の周波数が小さくなる ことによるものと推定され, 実際他のピークと同様に速 度が変化すれば周波数も変化することが確認されている.

\section{(3) 伝達過程における振動の変化}

$\mathrm{A}$ 高架橋及びB橋梁の橋脚下部における $500 \mathrm{~km} / \mathrm{h}$ 走行時 の1/3オクターブバンド振動レベルを図-8に示す. グラフ
の点線は複数列車における測定值の最大と最小を表して おり，実線は測定值の平均を表している．加振源に近い 側壁上部においてはA高架橋, B橋梁とも一部を除いて 同じ周波数にピークが現れていたが，橋脚下部における ピーク周波数はA高架橋で $4 \mathrm{~Hz}, 12.5 \mathrm{~Hz}, 40 \mathrm{~Hz}$ 付近，B橋 梁で6.3Hz，16〜20Hz，40Hz付近となっており，違いが 見られる.このうち, 軌道部分の振動（図-5参照）に見 られなかった，A高架橋の4HzとB橋梁の16〜20Hzは構造

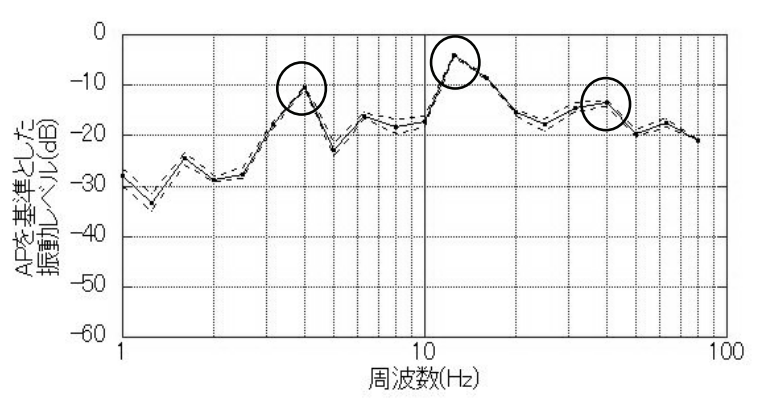

1) $A$ 高架橋

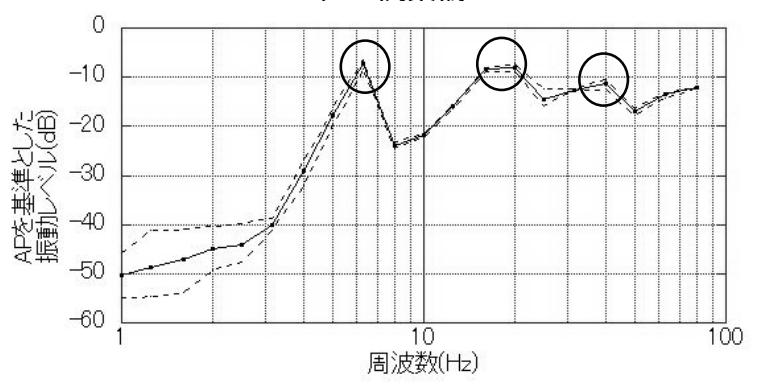

2) B橋梁

図-8 $500 \mathrm{~km} / \mathrm{h}$ 走行時の橋脚下部における 1/3オクターブバンド振動レベル
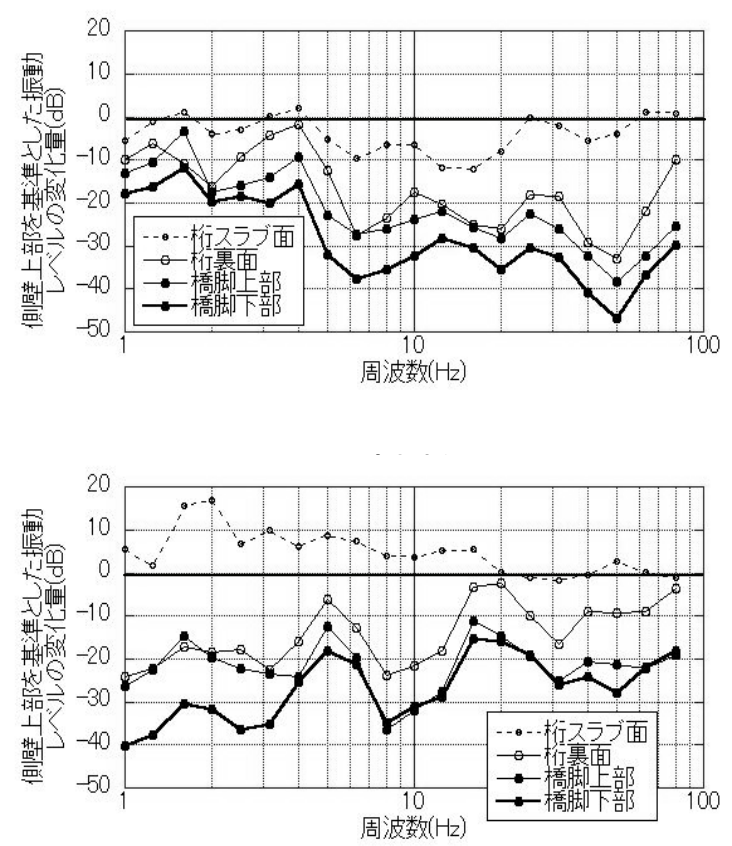

2) B橋梁

図-9 500km/h走行時の1/3オクターブバンド 振動レベルの構造物内伝達過程における変化 
物固有の振動特性に起因することが想定される.

側壁上部の1/3オクターブバンド振動レベルを基準に して，構造物の各計測点における1/3オクターブバンド 振動レベルを示したものが図-9である．側壁上部を基準 にした桁スラブ面の振動は，A高架橋では5Hzから $20 \mathrm{~Hz}$ にかけて減衰している一方，B橋梁では低い周波数の振 動が増加していることが確認されるが，特に側壁の振動 は計測する部位（今回の計測では側壁の支持点付近）に よって異なる可能性があり，更なる考察のためには詳細 な計測を要する．桁スラブ面から桁裏面，橋脚上部，橋 脚下部と伝播していくに従ってA高架橋，B橋梁とも振 動は減衰してきており，このうち桁裏面から橋脚上部に かけての減衰は枌のゴムシューの減衰に相当すると思わ れる. 周波数毎にみると，A高架橋では $4 \mathrm{~Hz}, 10 \sim 16 \mathrm{~Hz}$, $25 \mathrm{~Hz}$ の各帯域において減衰の度合いが少ない一方で， $\mathrm{B}$ 橋梁では5〜6.3Hz，16〜20Hzの带域で減衰の度合いが少 なく，傾向が異なっていることがわかる.

新幹線と比べた超高速鉄道の伝達特性を明らかにする ため，吉岡が整理した新幹線構造物の測定結果と今回の 測定結果を比較する. 吉岡の測定結果はラーメン高架橋 を中心に整理しており，直接的な相互比較はできないが， 各路線の標準構造における違いをマクロな観点から把握 することも重要と判断し，本論文においてはそのまま比 較を行った。その結果，

1) スラブ面から橋脚下部にかけての減衰の大きさは, 新幹線の高架橋では概ね $210 \mathrm{~dB}$ 強程度である ${ }^{4)}$ 一方, 超高速鉄道では図-9に示す通り, どちらの高架橋・ 橋梁においても概ね220dB以上減衰している.

2) 新幹線の高架橋では各周波数で比較的同じように減 衰が見られる 寸通り，どちらの高架橋・橋梁においても特定の 周波数で減衰の割合が少なくなる傾向がみられる。 1)の理由の1つとして浮上走行することによる影響が 考えられるが，これについては次節で述べる. その他, 桁構造の違いや，超高速鉄道の高架橋が新幹線に比べて マッシブ・リジッドなこと（超高速鉄道においては新幹 線と比較して許容たわみ量等を小さく抑えており ${ }^{12)}$ ，か つ特別な場合を除いてスパン長が長いため, 結果的に一 般的な新幹線の高架橋と比較して桁・橋脚ともマッシ ブ・リジッドとなっている），前述の林のゴムシューに よる減衰（APへの影響は $5 \mathrm{~dB}$ 程度）の3点も理由として 挙げられる.このうち2点目については吉岡の分析 ${ }^{4)}$ 10)に よれば析橋区間において，1スパン当たりの上部工コン クリート重量や橋脚重量が大きいほど振動レベルが低い 傾向があることが確認されている.

また2)の違いを生ずる原因としては超高速鉄道の各構 造物が持つ振動特性の影響や，基礎地盤の特性による影 響が考えられ，次章で考察を進めていく.

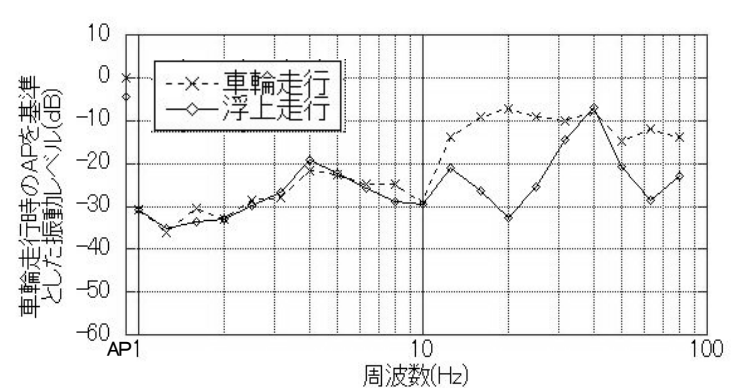

1) A 高架橋

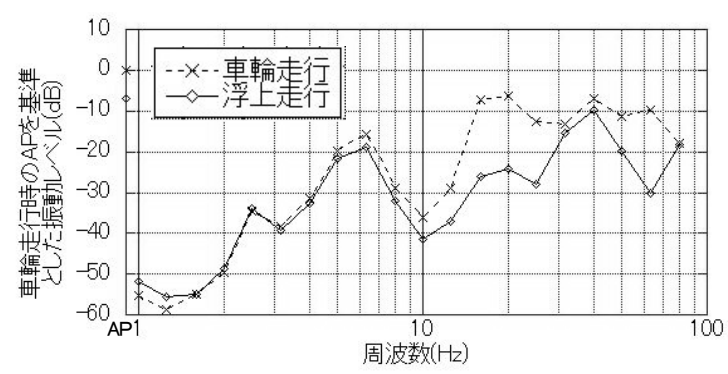

2) B橋梁

図-10 200km/h走行時の橋脚下部における 1/3オクターブバンド振動レベル (車輪走行時と浮上走行時の比較)
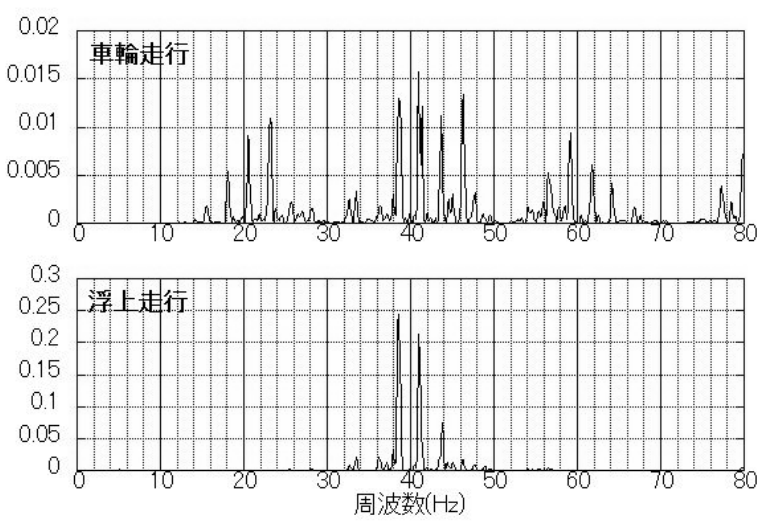

図-11Ａ高架橋200km/h走行時の橋脚下部における 正規化スペクトル

(車輪走行時と浮上走行時の比較)

\section{（4）走行形態が異なる場合の特性の違い}

超高速鉄道は浮上走行する点が既存の鉄道と異なって おり，この点が振動の発生・伝達に与える影響を検証す るため, 同じ $200 \mathrm{~km} / \mathrm{h} て ゙$ 車両が車輪走行した場合と浮上 走行した場合の比較を行う。なお通常は200km/hよりも 低い速度で車輪走行から浮上走行への移行を行っており， 今回の車輪走行は試験目的のために実施したものである. 橋脚下部における $1 / 3$ オクターブバンド振動レベル (車輪走行時のAPの振動レベルが基準) を図-10に示す。 $10 \mathrm{~Hz}$ 以下の周波数では車輪走行時と浮上走行時の差が 小さい一方，10Hzを超える周波数では $40 \mathrm{~Hz}$ を除き，浮 上走行時のレベルが低くなっている．特に浮上走行では $1.35 \mathrm{~m}$ の長さ（車両に搭載する磁石の極間隔）に起因す る40Hzの顕著なピークが確認される一方，車輪走行で 


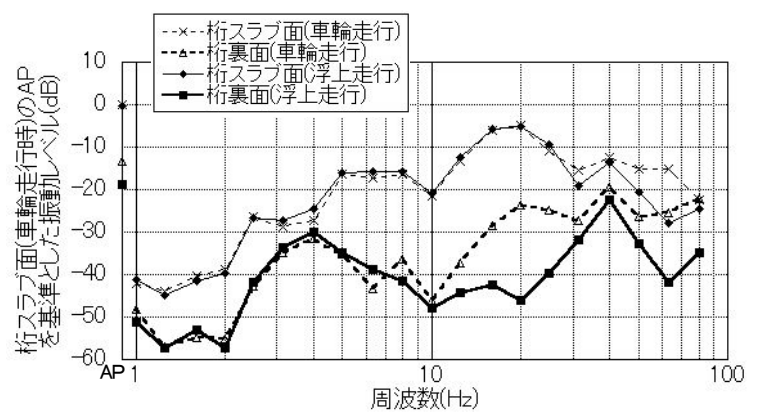

1) $A$ 高架橋

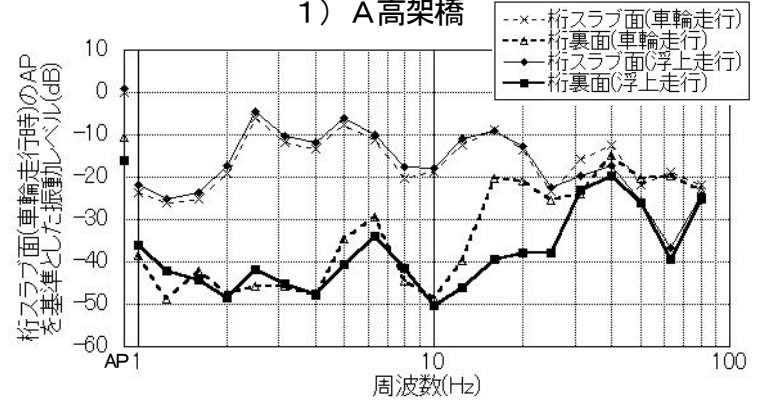

2) B橋梁

図-12 200km/h走行時の桁スラブ面，桁裏面における 1/3オクターブバンド振動レベル (車輪走行時と浮上走行時の比較)

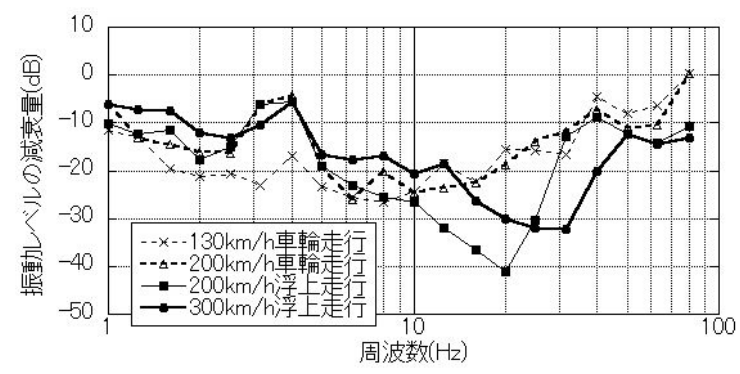

1) $A$ 高架橋

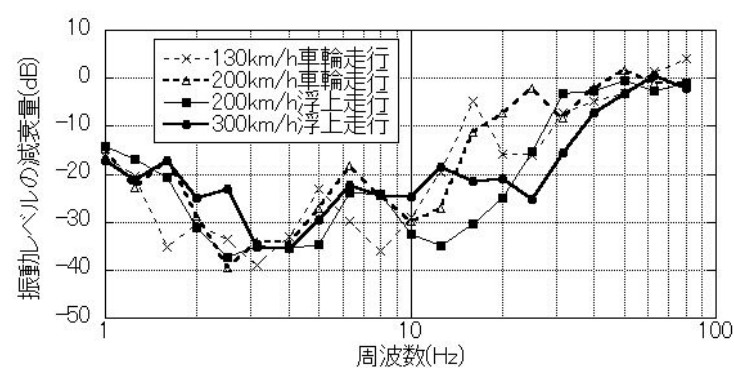

2) B橋梁

図-13 桁スラブ面から桁裏面にかけての 1/3オクターブバンド振動レベルの減衰量

は車軸間隔の $2.7 \mathrm{~m} に$ 起因する $20 \mathrm{~Hz}$ を含め, 広範な周波数 が卓越している．結果として，APの振動レベル（各グ ラフの左端に示している）も浮上走行の方が5〜 7dB小 さくなっている. 図-11に示す振動のパワースペクトル で比較しても，車両走行時は比較的広い周波数にピーク が見られるものの，浮上走行時はピークが $40 \mathrm{~Hz}$ 付近 (超電導磁石の極間隔に由来する周波数) に限定されて いる.

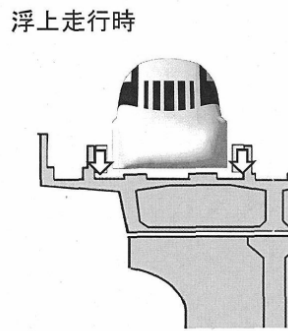

車輪走行時

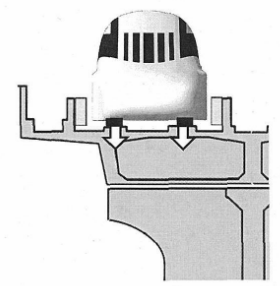

図-14 車輪走行時, 浮上走行時の荷重伝達の違い

$\mathrm{A}$ 高架橋及びB橋梁の桁スラブ面・桁裏面における $1 / 3$ オクターブバンド振動レベルを車輪走行時，浮上走行時 で比較した結果を図-12に示す。なお，車輪走行時の桁 スラブ面におけるAPの振動レベルを基準として表示し ている．桁構造の違いにも関わらず，どちらも桁スラブ 面の振動レベルは車輪走行時と浮上走行時で概ね同一傾 向であるが，桁裏面では $10 \mathrm{~Hz}$ を超える周波数で $40 \mathrm{~Hz}$ 付 近を除いて浮上走行時の振動がより減衰しており，橋脚 下と同一の傾向である.さらにこの傾向が車輪走行と浮 上走行の違いによるものであるかを確認するため，桁ス ラブ面から桁裏面にかけての振動レベルの減衰量を，車 輪走行時 $(130 \mathrm{~km} / \mathrm{h}, 200 \mathrm{~km} / \mathrm{h})$ と浮上走行時 $(200 \mathrm{~km} / \mathrm{h}$, $300 \mathrm{~km} / \mathrm{h})$ について整理した. その結果，どちらの高架 橋・橋梁においても図-13のように浮上走行時には車軸 間隔 $2.7 \mathrm{~m}$ に起因する周波数を中心に, 車輪走行時より減 衰量が大きいことがわかった。

図-14に示すように，車輪走行時は車両を支えるゴム タイヤに掛かる荷重が桁と一体となった走行路に直接作 用し，桁から橋脚，地盤と伝達される. 一方で浮上走行 時は走行する列車荷重の反力が複数の地上側のコイルに 作用し，更にその荷重がコイルを取付ける側壁に分散し て, 桁, 橋脚, 地盤と伝達されるといった違いがある. 詳細については今後さらに研究を進めていく必要はある が，こうした伝達経路の違いが振動の伝達・減衰特性に 影響を与え, 浮上走行時の振動レベルが小さくなったも のと考えられる.

\section{（5）地盤における伝達特性}

地盤における振動の伝達特性を検証するため, 構造物 中心及び9m離れ，12.5m離れ，25m離れの地点における， A高架橋及びB橋梁の $500 \mathrm{~km} / \mathrm{h}$ 走行時 $1 / 3$ オクターブバンド 振動レベルを，構造物中心におけるAPを基準として整 理した結果を図-15に示す．A高架橋では10〜25Hzの周波 数帯域において遠い地点で振動の増幅が見られ, 沿線地 盤においては $12.5 \mathrm{~Hz}$ のピークが顕著となっている. 一方 B橋梁では周波数による減衰の違いはあまり見られず, 結果として沿線地盤では6.3Hzの他，16〜 40Hzの広い周 波数帯域にピークが見られることが確認される. なお, B橋梁の $25 \mathrm{~m}$ 離れ地点は水路を挟んだ位置にあり，減衰 


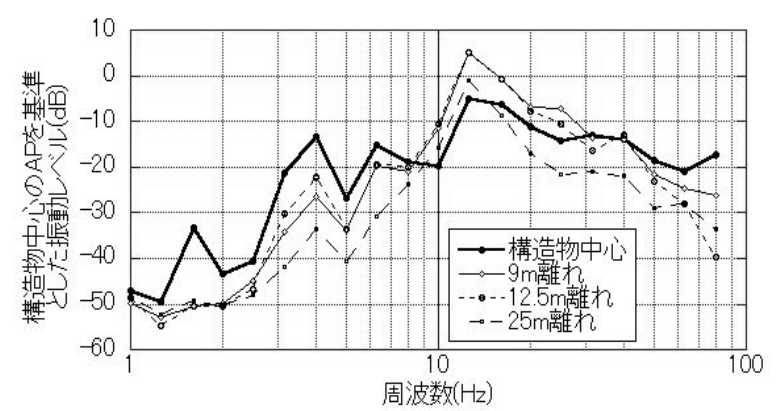

1) $A$ 高架橋

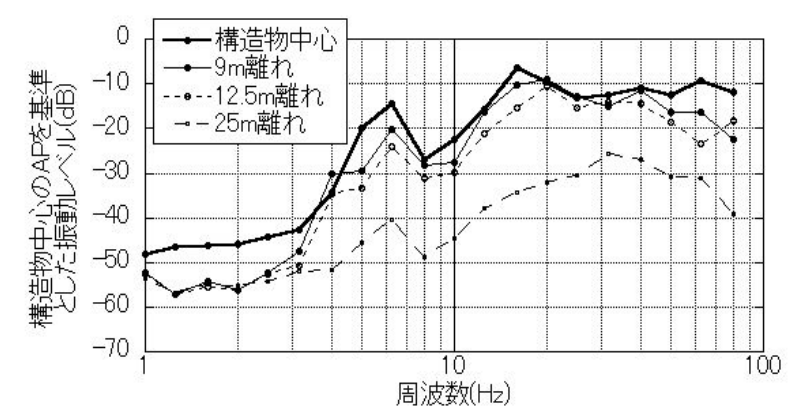

2) B橋梁

図-15 500km/h走行時の沿線地盤

における1/3オクターブバンド振動レベル

特性に影響を与えている可能性がある.

地盤における振動の伝達特性を更に検証するため, A 高架橋及びB橋梁において橋脚下部の振動に対する構造 物中心から9m離れの地点における振動の比率（伝達関 数）を整理したものを図-16に示す。新幹線鉄道建設時 の環境影響評価に用いられてきた測定例は12.5m離れや 25m離れの場合が多いが，超高速鉄道においてはこれま で技術評価 ${ }^{1)}$ に用いられている測定点を含め，9mない しは9.5m離れの地点で多く測定を行ってきたことから， 本研究における分析・評価は9m離れの地点を中心に進 めることとした. グラフは速度の変化による影響も含め て分析を行うため, $500 \mathrm{~km} / \mathrm{h}$ 走行時と $300 \mathrm{~km} / \mathrm{h}$ 走行時の結 果を併せて示している.これによれば，A高架橋におい ては速度に関わらず10〜30Hzの幅広い帯域で振動の増幅 傾向が見られ，特に $15 \mathrm{~Hz} ， 21 \mathrm{~Hz} ， 27 \mathrm{~Hz}$ 付近などは鋭い ピークを形成している．12.5m離れの地点においても同 様の傾向が確認される. その原因としては，表層と第二 層 (基礎地盤) のN值やS波伝達速度の違いが大きく， 表層の厚さや伝播速度の関係から表層の固有振動数の影 響を受けやすい状況にあるためと考えられるが，更に検 討が必要である. 一方B橋梁においては，特に増幅が見 られる周波数帯域はない.

なお，軟弱地盤上を列車が高速走行した場合，表層の 伝播速度と列車速度が合致し，沿線で大きな地盤振動が 観測される例が報告されている（例えば竹宮ら ${ }^{13)}$ ）。A 高架橋の沿線地盤における表層の伝播速度は経験式によ れば $160 \mathrm{~m} / \mathrm{s}$ 程度となり，500km/h走行時の速度（139m/s）

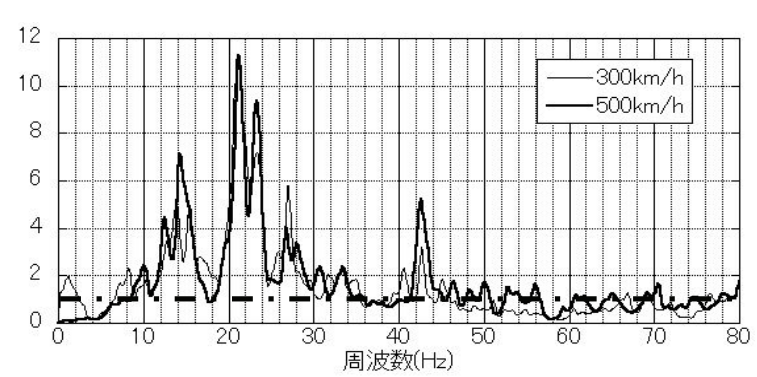

1) $A$ 高架橋

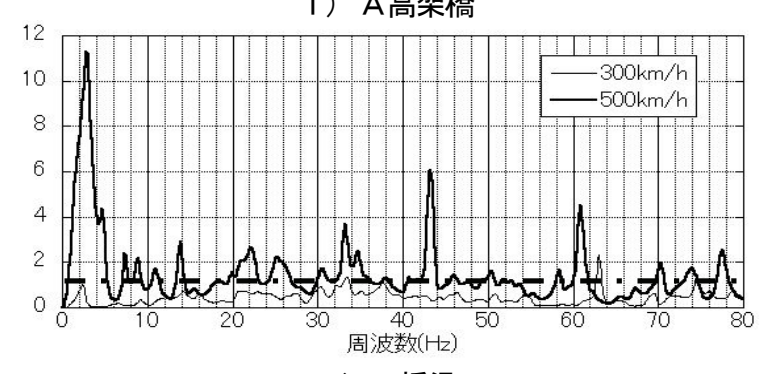

2) B橋梁

図-16 橋脚下部と9m離れの地点における振動の伝達関数

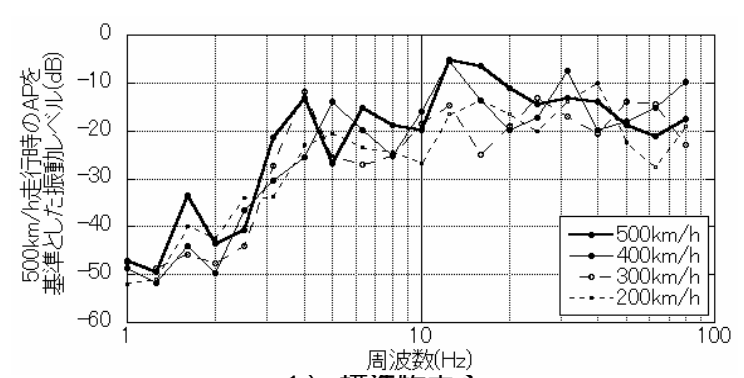

1) 構造物中心

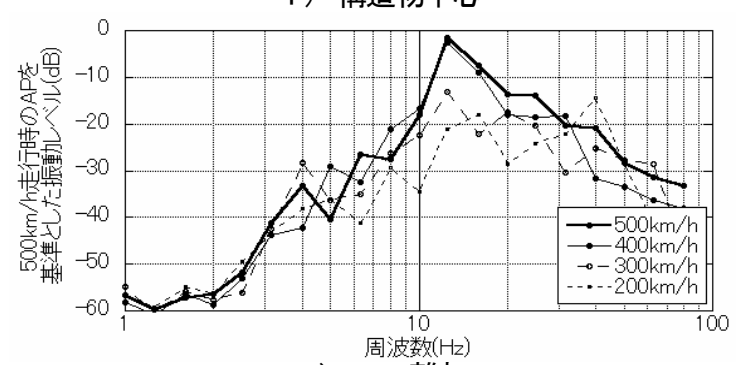

2) $9 \mathrm{~m}$ 離れ

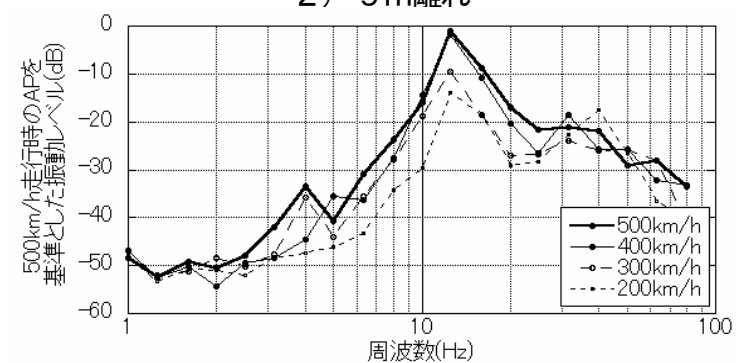

3) $25 \mathrm{~m}$ 離れ

図-17Ａ高架橋の沿線各地点における 1/3オクターブバンド振動レベルの速度による変化

に近接することから，同様の可能性について確認するた め, 図-17の通り, 構造物中心, $9 \mathrm{~m}$ 地点, $25 \mathrm{~m}$ 地点にお ける $1 / 3$ オクターブバンド振動レベルの速度による変化 の状況を整理し比較した. 地盤による増幅傾向の大きい 
10〜20Hzにおいて300km/hと400km/hの場合のレベル差が 大きくなっているが，400km/hと500km/hにおける差は小 さい. またこれ以外には速度に伴うレベルの変化が大き い箇所はなく, かつ位置の違う各地点において傾向は共 通している. そのためこれらを総合すると, 今回測定し たA高架橋においては，直近の橋脚からの振動に対して 離れた他の橋脚からの振動が重畳し，振動レベルに影響 を与えている可能性は低いと考えられるが，今後さらに 多くの条件で計測を行い，考察を深めていく必要がある. なおB橋梁においては表層の伝播速度が列車速度よりも 十分に速いと想定され，速度に伴うレベルの変化が大き い周波数はないことを測定結果からも確認している.

このように，超高速鉄道においても既存新幹線の高速 化における事例5) の同様に，地盤特性の影響で特定の 周波数の振動が増幅されることがあり, 振動值の予測・ 評価にあたっては，この点を考慮することも必要である.

\section{3. 構造物特性の振動への影響に関する考察}

前章の検討で，超高速鉄道においては加振源における 振動の特性に加え, 構造物や地盤の特性が沿線地盤振動 に大きく関係することが確認された，その中で，構造物 の特性が沿線地盤振動に与える影響について，桁たわみ 測定結果の分析と固有值モード解析により，さらに考察 を進める。

\section{(1) 桁の固有振動数と沿線地盤振動の関係}

構造物の影響により卓越していると想定される周波数 のうち, 低い周波数については杵の固有振動数が影響し ていると想定し，桁を車両が通過した後の自由振動時に おけるたわみ波形からフーリエ解析により梅の固有振動 数を算定して, 沿線地盤振動との比較を行った. 前述の A高架橋， B橋りょうの他，スパン $59.4 \mathrm{~m} の \mathrm{PC}$ 箱桁及びス パン25.2mのPCT桁であるC橋梁（概要を図-18に示す） においても, 構造物中心付近における地盤振動の1/3 クターブバンド振動レベル及び桁のたわみ波形のスペク トル（分散により正規化して表示）を測定し比較を行っ た. 結果を図-19に示す.

それぞれの桁において，たわみ波形の分析結果から把 握された固有振動数と1/3オクターブバンドで卓越して いる振動の周波数帯域が概ね一致することが確認される. これにより，A高架橋の地盤振動に見られる4Hzのピー クおよびB橋梁の6.3Hzのピークは構造物の固有振動が起 因していると考えられる．またC橋梁においては，観測 地点に近接する橋脚が支える二つの桁の固有振動数に係 るピークがそれぞれ確認されている．特にスパン $25.2 \mathrm{~m}$ の枌の固有振動数 $7.1 \mathrm{~Hz}$ は加振源でピークを現す $6.3 \mathrm{~Hz}$ の 周波数帯域に近く, 全体の振動レベルを支配している.

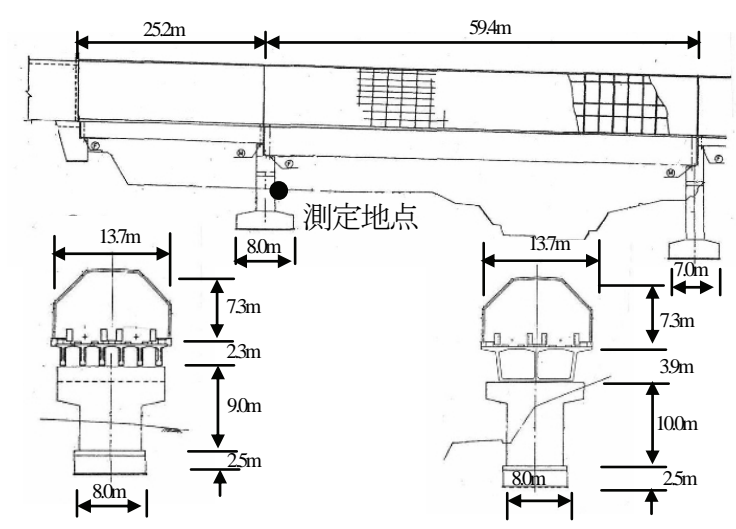

図-18 C橋梁の概要
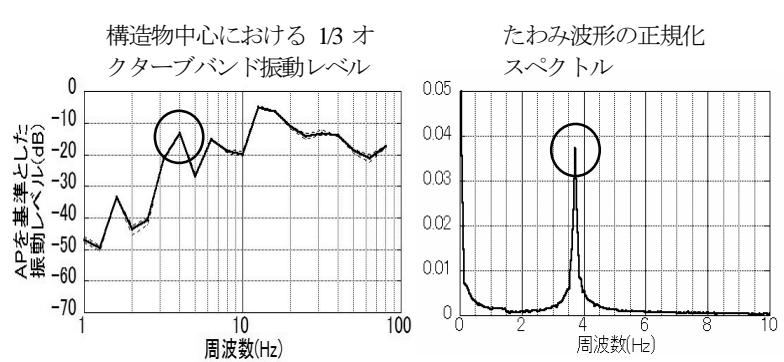

1) $A$ 高架橋

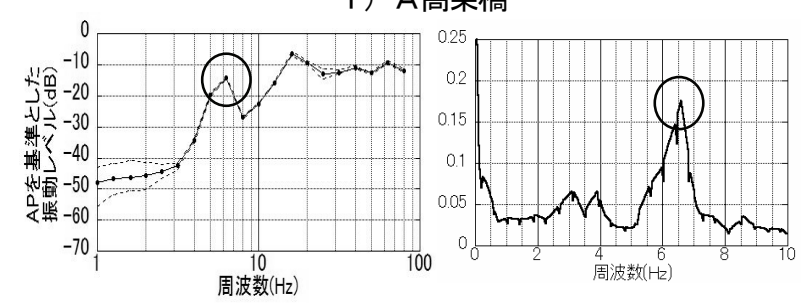

2) B橋梁

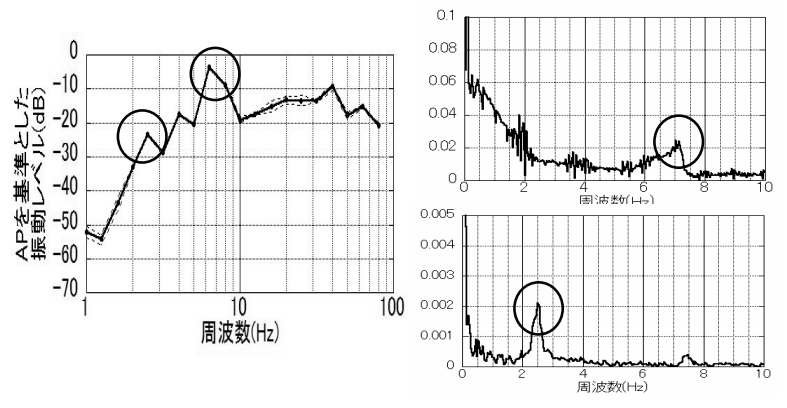

3）C橋梁

図-19 500km/h走行時の構造物中心における 1/3オクターブバンド振動レベルと桁たわみの関連

\section{（2）高架橋全体の振動モードと沿線地盤振動の関係}

前項の検討により, 桁の固有振動数と沿線地盤振動で 卓越している周波数に関連があることがわかったが，さ らに高次の振動モードによる影響も考えられるため，A 高架橋を対象に高架橋全体の振動モード解析を実施して, その結果と沿線地盤振動との比較を行うことを考えた. 今回作成した解析モデルの概要を図-20に, 設定した材 料定数を表-1に示す. 7連の単純林から構成され, この うちP2及びP3は杭基礎，その他は直接基礎となっている. 


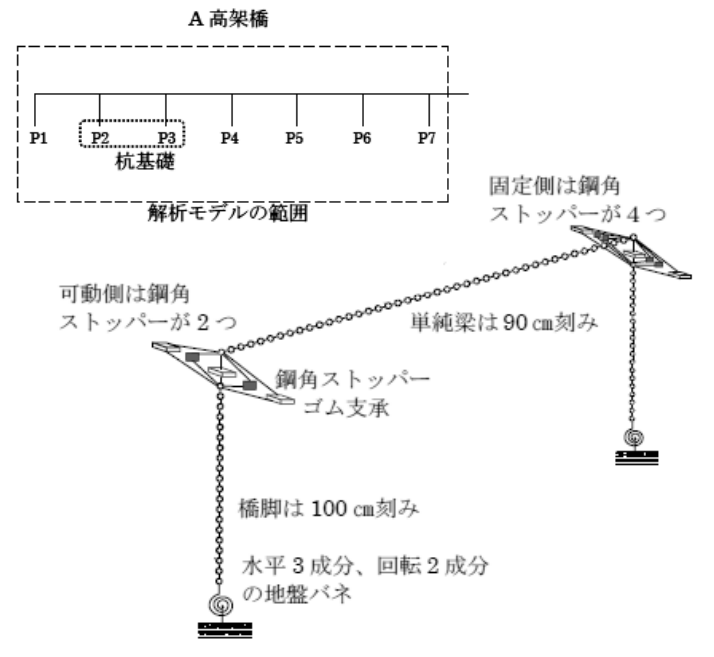

図-20 A高架橋固有值解析モデル

表-1 各部材の詳細条件

\begin{tabular}{|c|c|c|}
\hline 部材名 & 要素種類 & 条 件 \\
\hline 桁 & 梁要素 & 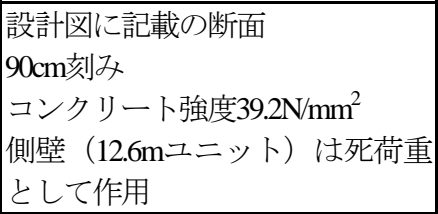 \\
\hline ゴム支承 & ばね要素 & 水平2方向と上下方向に設定 \\
\hline $\begin{array}{l}\text { 鋼角 } \\
\text { ストッパ }\end{array}$ & 梁要素 & $\begin{array}{l}\text { 固定側は全断面有効と算定 } \\
\text { 移動側は無視 }\end{array}$ \\
\hline 橋脚 & 梁要素 & $\begin{array}{l}\text { 設計困に記載の断面 } \\
100 \mathrm{~cm} \text { 刻み } \\
\text { コンクリート強度 } 23.5 \mathrm{~N} / \mathrm{mm}^{2}\end{array}$ \\
\hline $\begin{array}{l}\text { 地盤 } \\
\text { 及び } \\
\text { 基礎杭 }\end{array}$ & 地盤ばね & $\begin{array}{l}\text { 杭基礎の場合は地盤定数と群杭 } \\
\text { の影響を考慮した3次元薄層法に } \\
\text { より複素ばねを設定 } \\
\text { 直接基礎の場合は地盤定数と動 } \\
\text { 的地盤インピーダンスより基礎 } \\
\text { 底面の地盤ばねを設定 }\end{array}$ \\
\hline
\end{tabular}

14次モード(3.8Hz)

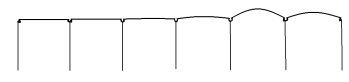

44次モード(14. 7Hz)

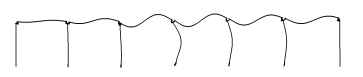

35次モード(12. 6Hz)

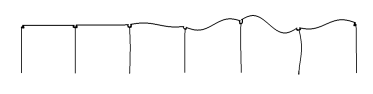

48次モード(16. OHz)

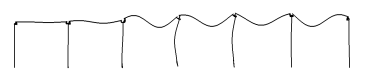

図-21 A高架橋の卓越振動モード（鉛直方向）

なお沿線地盤振動の測定箇所はP6付近である.

固有值解析の結果を図-21に示寸，解析は水平2方向,

鉛直方向の計3方向について行ったが，ここでは50次ま でのモードのうち，鉛直方向の成分が卓越しているモー ドを抽出している．このうち14次モードは枌の単純上下

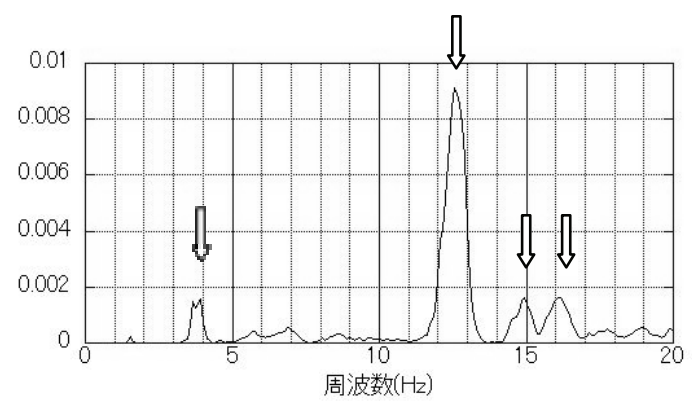

図-22 A高架橋 $500 \mathrm{~km} / \mathrm{h}$ 走行時の橋脚下部正規化パワー スペクトルと解析による固有振動数（矢印）の比較

振動モードであり，前項で桁たわみ波形から算定した固 有振動数にほぼ一致している。.また35次モードは桁の変 形とともに橋脚が橋軸方向に変形寸るモードであり，橋 軸方向と上下方向のそれぞれの振動が卓越する.この結

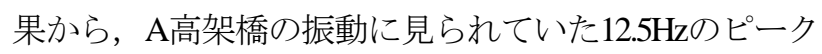
は, 車両の繰り返し荷重効果のほか, 構造物の固有振動 数にも起因していると考えられる.

図-22は，A高架橋500km/h走行時の橋脚下における構 造物振動を正規化パワースペクトルで表した図であり, これに図-21で卓越していた周波数を示すと矢印の通り となり，構造物において卓越しているピークと一致する ことが確認できる.

上記のことから，超高速鉄道においては構造物の振動 特性が沿線地盤振動に強い影響を及ぼしていることが, たわ久測定結果の分析と固有值モード解析の結果からも 裏付けられたと言える。

以上述べてきた実駼線の測定結果に基づく評価及び考 察の結果, 超高速鉄道における地盤振動の特徵として

1) 超高速鉄道の軌道部分で発生する振動は車両の台車 間隔や超電導磁石の極間隔による規則的な加振の影 響を強く受けており，新幹線と同様の傾向を持つ.

2) 超高速鉄道においては，浮上走行に伴って，10Hz以 上の周波数成分が極間隔 $1.35 \mathrm{~m}$ に起因する特定の周 波数を除いて車輪走行時より桁において大きく減衰 している. この傾向は桁構造の違う橋梁においても 同様に確認されており, 荷重伝達の違いが影響して いると考えられる.

3）超高速鉄道では2)に加え，高架橋における振動の減 衰が新幹線に比べて全体的に大きく，さらには枌 の固有振動数等, 構造物特性の影響により特定の 周波数において減衰量が少なくなる傾向がある. その結果，橋脚下部において軌道部分では顕著で なかった新たな周波数のピークが形成されている.

4) 新幹線と同様, 超高速鉄道においても地盤の状況に よっては，沿線地盤において振動が増幅される場 合があり，振動の予測・評価にあたっては，地盤 特性の影響を考慮する必要がある. 
の4点が確認された. これらは，本研究により初めて明 らかにされた事実であり，営業線における沿線地盤振動 を的確に予測・評価するためには，新幹線で培われた知 見に加え，これらの特徴を反映していくことが必要であ る. 次章においては，実測結果を反映した数值解析モデ ルの構築により，超高速鉄道における沿線地盤振動を予 測・評価した成果について論じる.

\section{4. 数值解析による沿線地盤振動の予測・評価}

\section{（1）構造物と地盤のシミュレーション解析手法}

本章では，前章までの検討において確認した構造物の 振動特性や地盤の特性を反映した数值解析を実施し, 超 高速鉄道の営業線で想定される種々の条件における沿線 地盤振動を予測・評価するためのモデルを構築すること を考える.

\section{a) モデル化の手法}

従来，新幹線のラーメン高架橋においては柱，梁，ス ラブ等, 高架橋を構成する各要素を線材要素やシェル要 素でモデル化し，車両から受けるモデル化された加振力 を移動しつつ載荷する方法などにより構造物振動の予測

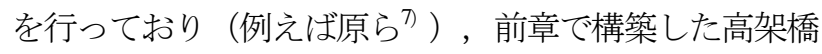
のモデルに別途設定する超高速鉄道の荷重を作用させる ことで同様の予測を行うことは可能であるが,

・超高速鉄道では環境対策工として明かりフード等を 設置する場合があり，特に線材要素におけるモデ ル化の難易度が高くなる

・種々の構造物や地盤条件の影響を考慮するため，構 造物と地盤を一定の考え方で取扱うことのできる モデルが望ましい

ことから別のモデル化手法を検討し，その結果，人体や 浸透流，広域な地震波伝播の解析等に用いられているボ クセル有限要素法 ${ }^{14)}$, 15), 16), 17) に着目して解析を進めること とした.

通常のFEM解析における三次元メッシュ作成にはエン ジニアの手作業に要する部分が多く, 解析作業の面でも 大部分を占めると言われている ${ }^{16)}$ 一方，ボクセル有限 要素法は三次元形状を等しい大きさの立方体要素（ボク セル）に分割して表現するものであり，

1）形状が非常に複雑であっても，確実かつ高速にモデ リングが行え，形状が変わる場合等にも容易に解 析を追従させることができる

2) 要素形状が単一なので要素マトリックスを全て記憶 する必要がなく，要素結合情報が少なくて済むこ となどから，大幅な記憶容量の削減が可能になり， 通常のFEMより格段に細かいメッシュによる解析が 可能になる

という利点がある．本研究は超高速鉄道の営業線におけ
る沿線地盤振動の予測モデル構築を目的とするものであ ることから，種々の構造物（側壁や明かりフードについ ても考慮する必要がある）や地盤条件に対応した解析を 行い, その結果を相互に比較出来ることが望ましい. そ こで前述の1)のメリットに着目し，この手法を用いるこ ととした.

\section{b) 高架橋と地盤のモデル}

解析に用いた高架橋・橋梁及び地盤のモデル図を図23に，設定した構造物モデルの材料定数を表-2に示す. 計算の効率化を図るため, 高架橋・橋梁モデルと地盤モ デルを分離し，2段階で解析を実施した.

明かりフードは最小厚さが10cmであることから，形 状の再現性を考慮して高架橋・橋梁については10cm ッシュのボクセル要素でモデル化した. 実測結果から隣 接する橋脚からの影響は小さいものと想定し，A高架橋， B橋梁とも2連の桁モデルで解析を行った．また，地盤 については実測值で励起されている振動数とせん断波速 度を考慮して30cmメッシュのボクセル要素で水平成層 モデルを構築した（B橋梁においても，ボーリングデー

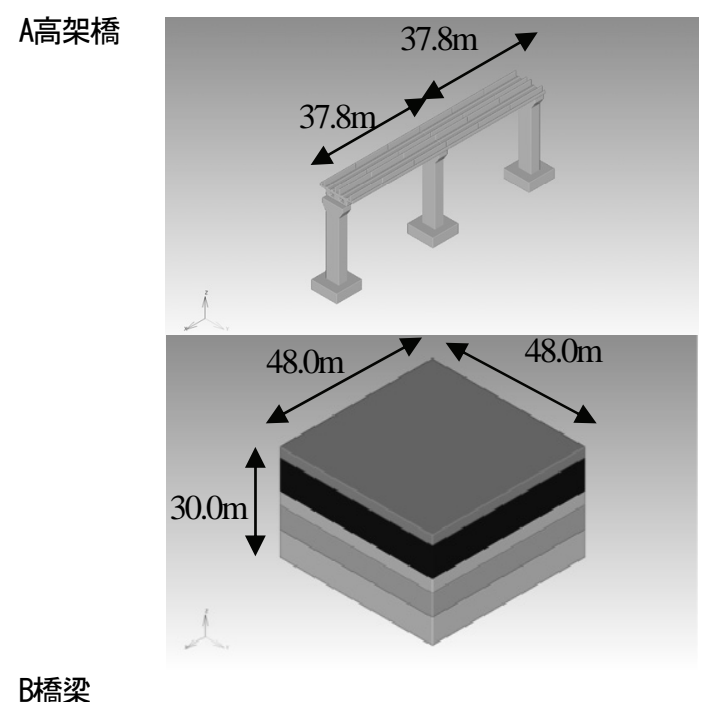

B橋梁

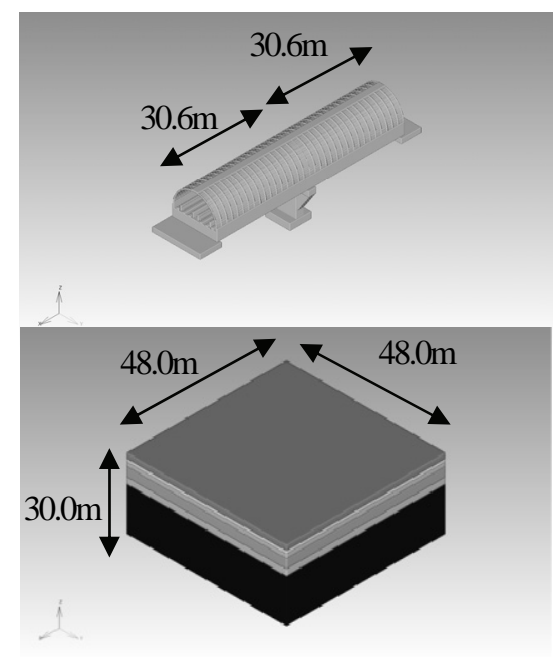

図-23＼cjkstart高架橋及び地盤のボクセルモデル 
表-2 高架橋構造物モデルの材料定数

\begin{tabular}{|l|l|c|l|}
\hline \multicolumn{1}{|c|}{ 部位 } & $\begin{array}{c}\text { ヤング率 } \\
\left(\mathrm{N} / \mathrm{m}^{2}\right)\end{array}$ & ポアソン比 & $\begin{array}{c}\text { 単位体積 } \\
\text { 重量 } \\
\left(\mathrm{kg} / \mathrm{m}^{3}\right)\end{array}$ \\
\hline 側壁 & $3.2 \times 10^{10}$ & 0.2 & $2.5 \times 10^{3}$ \\
\hline フード & $3.2 \times 10^{10}$ & 0.2 & $2.5 \times 10^{3}$ \\
\hline 桁 & $3.2 \times 10^{10}$ & 0.2 & $2.5 \times 10^{3}$ \\
\hline ゴム支承 & $8.8 \times 10^{8}$ & 0.475 & $9.4 \times 10^{2}$ \\
\hline 橋脚 & $2.7 \times 10^{10}$ & 0.2 & $2.5 \times 10^{3}$ \\
\hline
\end{tabular}

タが限られていることから水平成層として予測した）。 各モデルとも全要素で8点積分としている，なお，地盤 モデルへの入力は, 高架橋モデルでの橋脚（フーチング をモデル化）における軸力とした．表-3に示寸ボーリン グテータに基づいて地盤各層におけるせん断波速度を算 出し, 高架橋・橋梁モデルにおいては3次元薄層要素法 により算出した地盤ばねを橋脚端部に設定している．地 盤モデルにおいては，底面及び側面を粘性境界とした。

今回の予測にあたっては，計算の効率化を考慮して高 架橋・橋梁モデル，地盤モデルともに質量比例型の減衰 を設定した. パラメータスタディにより実測值との整合 性を検証し，どちらのモデルにおいてもA高架橋では 10Hzで1.5\%，B橋梁では10Hzで3.0\%となる減衰とした.

なお，解析の刻み時間はクーランの安定条件から設定 し, 高架橋・橋梁モデルでは約 $1 / 40,000$ 秒, 地盤モデル では約1/10,000秒としている.

\section{c) 加振力の設定}

列車走行時の加振力については以下の通り設定した. まず，車両を浮上させる力が車両に搭載している磁石に 働き，その反作用として側壁が荷重を受けることとなる. 本研究においては，台車間隔や台車内の磁石の間隔等を 考慮して, 図-24の通りモデル化した. その後, 1つのコ イルがもたらす加振力のうち, 最大加振力に達するまで の時間及び最大加振力の作用時間をパラメータとして, 実測值との整合性が最も高い加振力を選定した．結果を 図-25に示す．なお最大加振力については，各台車が支 持する荷重の大きさから算定した.

\section{（2）測定結果と解析値の比較}

前項までに設定した高架橋, 地盤の3次元立体解析モ デル及び加振力モデルを用いて，車両が走行する際の高 架橋及び沿線地盤における振動応答を計算し, 実測值と の比較を行った．計算はA高架橋及びB橋梁の $500 \mathrm{~km} / \mathrm{h}$ 走 行時の列車を対象に実施した他，加振源に起因する周波 数成分と基礎地盤を含めた構造物特性に由来する周波数 成分が解析上再現されていることを確認するため，A高 架橋 $400 \mathrm{~km} /$ 走行時についての計算も行った.

A高架橋における $500 \mathrm{~km} / \mathrm{h}$ 走行時と $400 \mathrm{~km} / \mathrm{h}$ 走行時の橋 表-3＼cjkstart地盤モデルの基礎となるボーリングデータ

A高架橋

\begin{tabular}{|c|c|c|c|}
\hline $\begin{array}{l}\text { 層厚 } \\
(\mathrm{m})\end{array}$ & $\begin{array}{c}\text { 深度 } \\
(\mathrm{m})\end{array}$ & 土質名 & $\begin{array}{l}\text { N值 } \\
\text { (回) }\end{array}$ \\
\hline 0.3 & 0.3 & 表土 & \\
\hline 2.8 & 3.1 & ローム & 4 \\
\hline 9.0 & 12.1 & 砂砶 & 81 \\
\hline 3.9 & 16.0 & ローム & 11 \\
\hline 6.5 & 22.5 & $\begin{array}{l}\text { 砂質シルト及び } \\
\text { シルト質砂 }\end{array}$ & 12 \\
\hline 6.5 & 29.0 & 強風化凝灰岩 & 197 \\
\hline
\end{tabular}

B橋梁

\begin{tabular}{|c|c|c|c|}
\hline $\begin{array}{c}\text { 層厚 } \\
\text { (m) }\end{array}$ & $\begin{array}{c}\text { 深度 } \\
\text { (m) }\end{array}$ & 土質名 & $\begin{array}{l}\text { N值 } \\
\text { (回) }\end{array}$ \\
\hline 0.5 & 0.5 & 表土 & \\
\hline 1.1 & 1.6 & 粘土混じり砂磁 & 24 \\
\hline 0.8 & 2.4 & 砂質シルト & 4 \\
\hline 1.1 & 3.5 & 粘土混じり砂碩 & 14 \\
\hline 2.6 & 6.1 & 礫混じり砂礫シルト & 4 \\
\hline 1.9 & 8.0 & 砂礫 & 34 \\
\hline 13.0 & 21.0 & 安山岩 & 50以上 \\
\hline
\end{tabular}
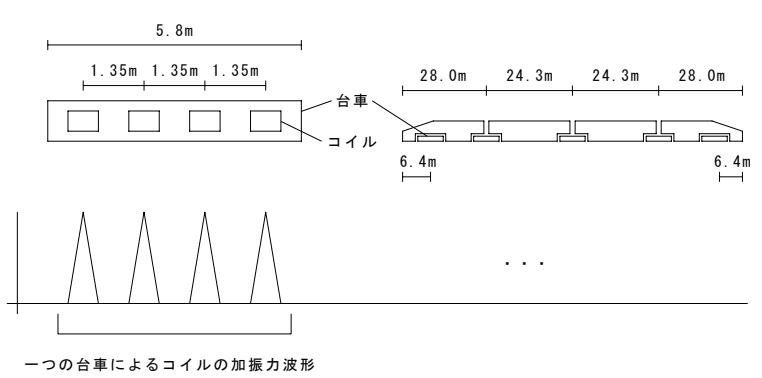

図-24 列車荷重のモデル化概要

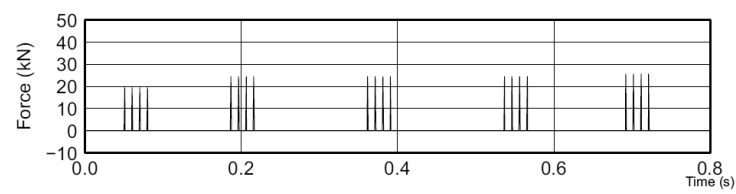

図-25 設定した加振力

脚下部の振動の予測值と実測值について, 実測值のAP を基準とした $1 / 3$ オクターブバンド振動レベルで比較し た結果を図-26に示寸． 500 km/h走行時には，予測值にお いて台車間隔に由来する $6.3 \mathrm{~Hz}$ 成分の減衰が少なく, 実 測值に比べてピークがやや目立っているものの, 構造物 特性に起因する $4 \mathrm{~Hz}$ 付近のピークや加振力成分・構造物 特性双方に起因寸ると考えられる12.5HzといったAPの振 動レベルに影響の大きなピークが確認される。一方 


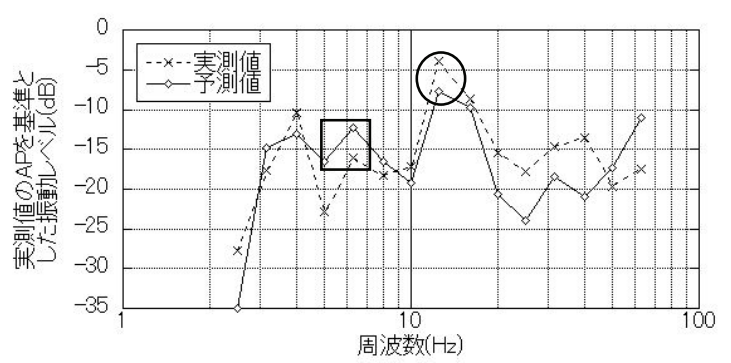

1) $500 \mathrm{~km} / \mathrm{h}$

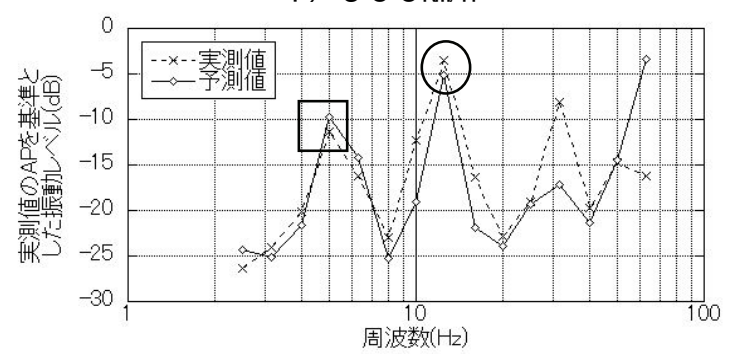

2) $400 \mathrm{~km} / \mathrm{h}$

図-26 500km/h $400 \mathrm{~km} / \mathrm{h}$ の予測值 - 実測值比較 (A高架橋の橋脚下部)

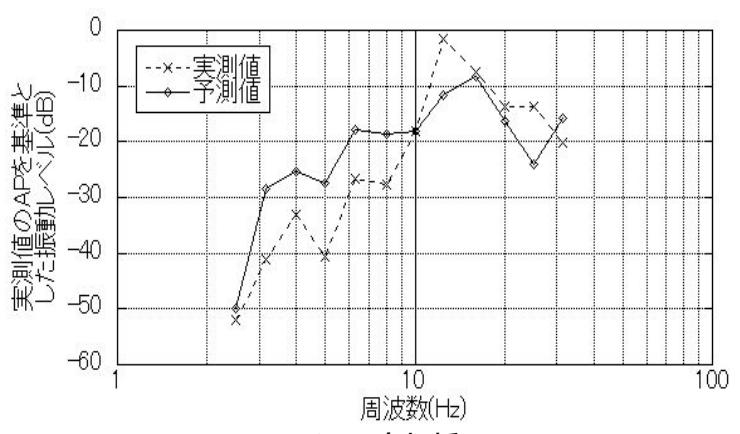

1) $A$ 高架橋

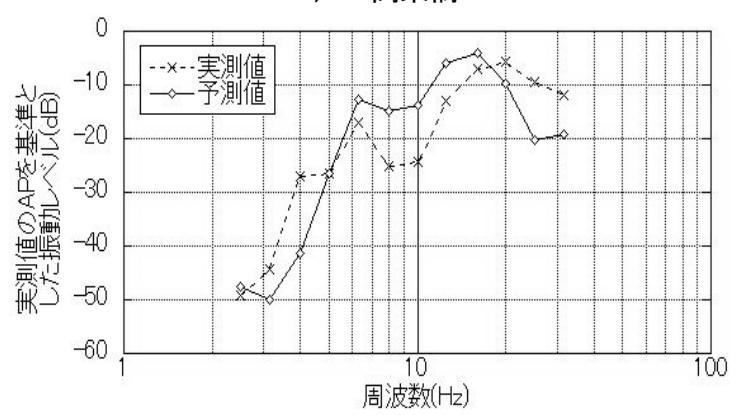

2) B橋梁

図-27 500km/h走行時の沿線地盤振動(9m離れ) に関する予測值・実測值比較

$400 \mathrm{~km} / \mathrm{h}$ 走行時においては，台車間隔に起因し実測值に 見られる5Hzのピークが解析結果においても顕著にみら れており，構造物特性に起因すると考えられる $12.5 \mathrm{~Hz} の$ 成分にもピークが確認される。 つまり，加振力成分に由 来し速度依存性のある周波数成分と，構造物特性に由来 し速度依存性のない周波数成分のそれぞれが，解析上も 現われているといえる.

さらに，500km/h走行時の構造物中心から9m離れの地 点において，実測值のAPを基準とした1/3オクターブバ

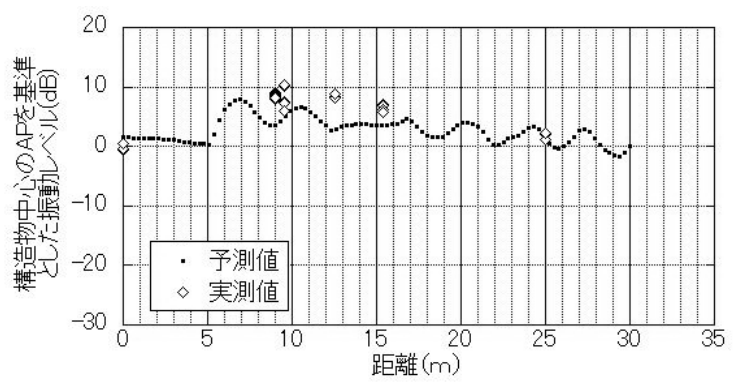

1) $A$ 高架橋

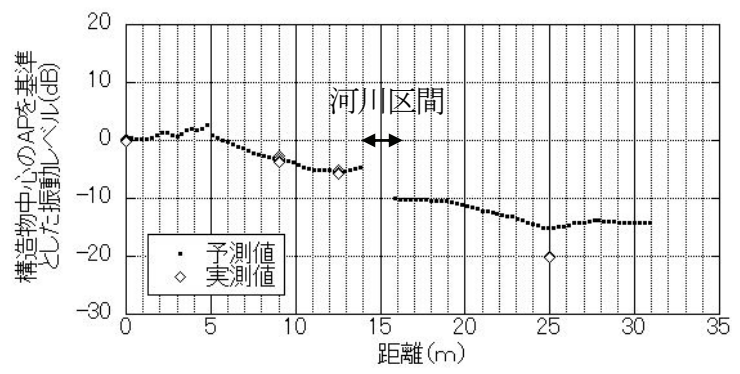

2) B橋梁

図-28 構造物中心からの離れ毎の予測值・実測值比較 (500km/h : 構造物中心のAP振動レベルを基準)

ンド振動レベルで実測值と予測值を比較した結果を図27に示す. A高架橋の沿線地盤では，10Hz以下の低い周 波数帯域において予測值が実測值より全体的に大きい等 の相違点はあるものの，10～20Hzの帯域で振動が卓越す る傾向を解析上も確認した. なお $9 \mathrm{~m}$ 地点では12.5Hzのレ ベルが16Hzより小さく予測されているが，大半の距離 においては実測值と同様，12.5Hzのレベルが最も高いと 予測される. B橋梁についても同様に予測值においては, 実測值ほど顕著ではないものの構造物特性に起因すると 考えられる $16 \mathrm{~Hz}$ のピークが現れており，加振力成分・ 構造物特性双方に起因すると考えられる6.3Hzのピーク とともに，実測值に見られる特徴をよく表している．ま た6.3〜 12.5Hzの低い周波数においては予測值のレベルが 大きくなり，25Hz以上の高い周波数においては実測值 のレベルが大きくなるという点は異なるものの，ピーク を形成する周波数は概ね一致しており，特に全体のピー クを構成する16〜20Hzの振動レベルは概ね同程度となっ ている.

解析結果に基づき構造物中心からの離れ毎にAP振動 レベルを予測し，実測值（同箇所において，本研究以外 で実施した測定結果も含む）と比較した結果を図-28に 示す.

$\mathrm{A}$ 高架橋の沿線地盤においては，増加・減少を周期的 に繰返しながら構造物中心からある一定の距離までは全 体として振動レベルが増加し, 更に離れると減少すると 予測している．増加・減少の繰返しについては解析上特 定の周波数の振動が卓越するために発生するものであり， 実際の状況とは異なると考えられるが，一定の距離まで 
増加する点については, これまで実測值で確認された事 象を解析に反映できたといえ，予測される振動レベルの 最大值は実測值のばらつきの範囲内にある．またB橋梁 の沿線地盤においては，9m離れ，12.5m離れの地点では 予測值が概小実測值の平均程度となっており，全体的な 減衰の傾向も実測值の特徴を捉えている。 なお $25 \mathrm{~m}$ 地点 では予測值が実測值を大幅に上回った結果となっている が，これは現地の制約上，測定点が構造物に対して水路 を挟んだ位置にあり，この影響で振動が大きく減衰して いるためと考えられる.

\section{（3）営業線条件における予測}

前項の検討の結果, 数值解析モデルにより沿線地盤振 動の最大值について実用上十分な精度で予測可能である ことがわかった．本項では，営業線における様々な条件 を想定して地盤振動レベルの予測を行い，新幹線の勧告 值を十分に達成可能であることを示す.

\section{a) 予測条件}

予測は標準高架橋形式であるA高架橋および両編成 車両のモデルを基本とし，表-4に示寸各条件において実 施した.

\section{b) 予測結果}

基本ケースの予測值と表-4の通り条件を変化させたケ 一スの予測值について, 離れ毎の振動レベル（構造物中 心における500km/h走行時の実測值を基準として表示) 変化と1/3オクターブバンド振動レベルの変化の $2 つ の$ 観 点から比較を行う。なお後者については前章における実 測結果と同様の理由から，500km/h走行時の構造物中心 から9m離れの結果を示している.

車両編成長が試験車両である4両編成の場合と, 営業 線を想定した16両編成の場合を比較した結果を図-29に 示す．離れ毎に細かい周期で増加と減少を繰り返してい るものの全体的なレベルはほとんど変わらず，1/3オク ターブバンド振動レベルでも比較してもほとんど違いが

表-4 予測の実施ケース

\begin{tabular}{|c|c|}
\hline 番号 & 予測条件 \\
\hline 1 & $\begin{array}{l}\text { 基本ケース } \\
\text { (4両編成車両，高架橋高さ23m, } \\
\text { 防音壁付き，A高架橋実地盤) }\end{array}$ \\
\hline 2 & 車両編成長変更ケース(4両 $\rightarrow 16$ 両) \\
\hline 3 & 高架橋高さ変更ケース(23m—10m) \\
\hline 4 & $\begin{array}{l}\text { 環境対策工変更ケース } \\
\text { (防音壁↔明かりフード) }\end{array}$ \\
\hline 5 & $\begin{array}{l}\text { 地盤変更ケース } \\
(\mathrm{A} \text { 高架橋実地盤の表層厚を } 3 \mathrm{~m} \rightarrow 10 \mathrm{~m} \\
\text { に変更 : 基礎は直径 } 1.5 \mathrm{~m} \text { の鉄笳コンク } \\
\text { リート杭4本をモデル化) }\end{array}$ \\
\hline
\end{tabular}

見られないことがわかる．なお実際の測定では振動レベ ル計の時定数の関係で4両編成と16両編成の指示值は約 $1 \mathrm{~dB}$ 異なることがわかっているが，この点については図 において考慮されていない。

また，高架橋高さを実測の23mから10mに変化させた 場合で比較した結果を図-30に示寸，高架橋高さ $10 \mathrm{~m} の$ 場合, どの地点においても $\mathrm{AP}$ 振動レベルは概ね2 $2 \mathrm{~dB}$ 程度

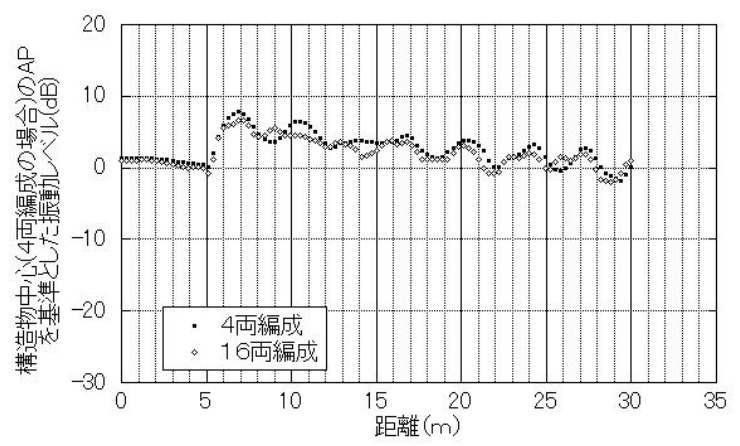

a）離れ毎のAP振動レベル変化

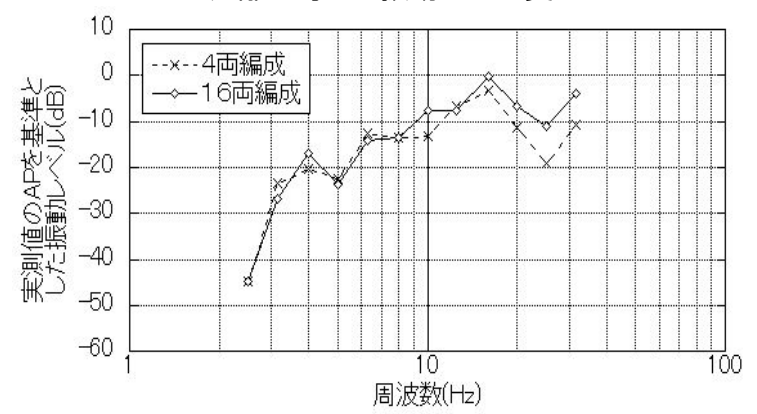

b ） $1 / 3$ オクターブバンド振動レベル

図-294両編成車両と16両編成車両の予測值の比較

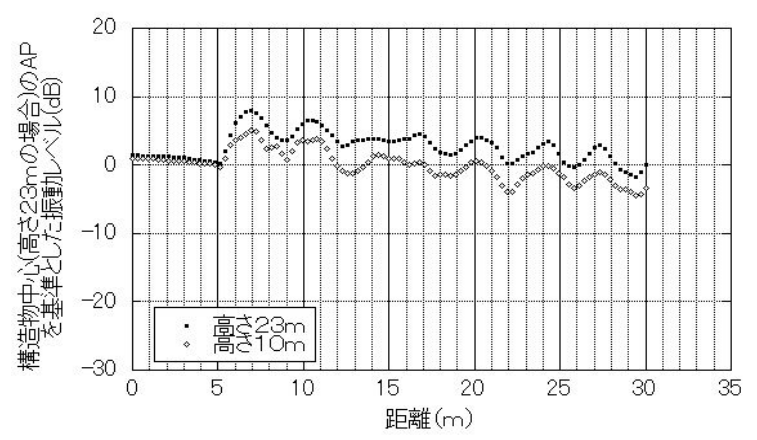

a）離れ毎のAP振動レベル変化

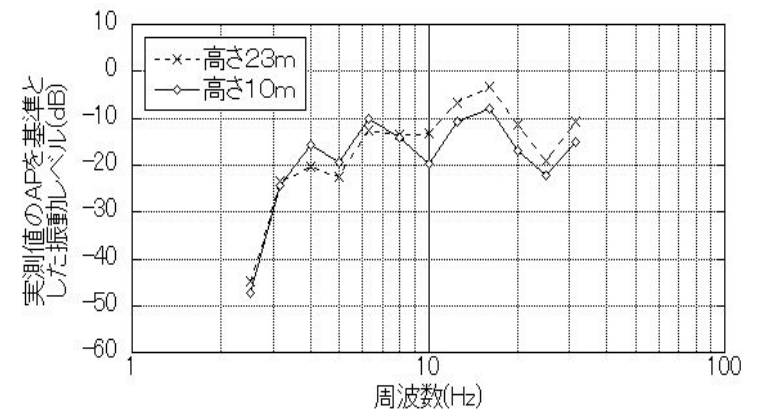

b ） $1 / 3$ オクターブバンド振動レベル

図-30 高架橋高さ23mと10mの予測值の比較 
低くなっている．またピークの位置等，周波数構成の変 化はないものの，10Hz以上で全体的な振動レベルの低 下が見られる．高架橋高さの変化により高架橋の鉛直振 動モードが変化し，その影響を受けた可能性がある.

環境対策工として防音壁を設置した場合と明かりフー ドを設置した場合を比較すると図-31の通りとなる．全

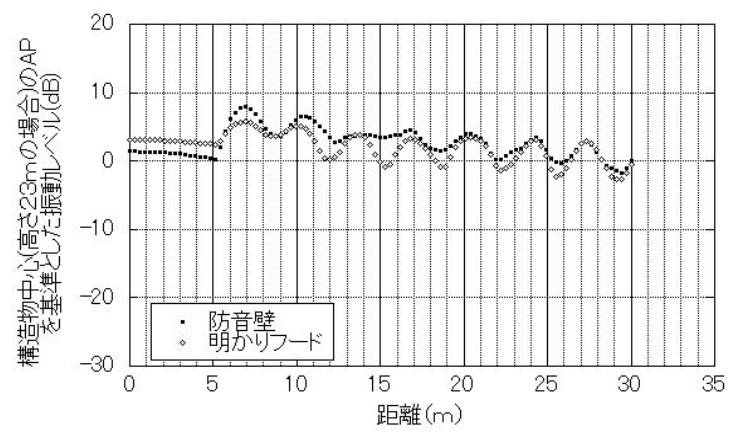

a）離れ毎のAP振動レベル変化

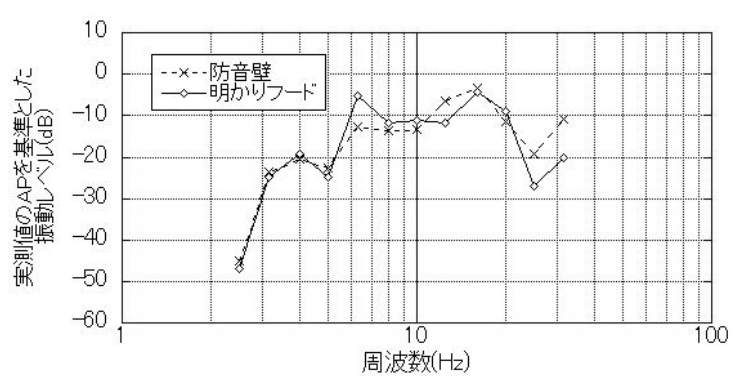

b ） $1 / 3$ オクターブバンド振動レベル

図-31防音壁と明かりフードの予測值の比較

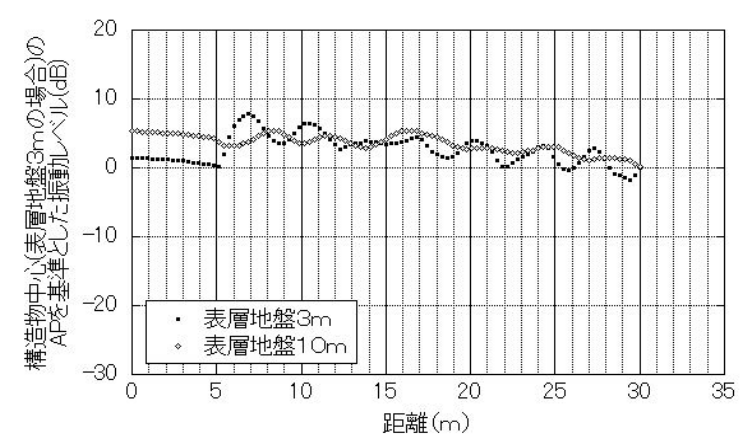

a ）離れ毎のAP振動レベル変化

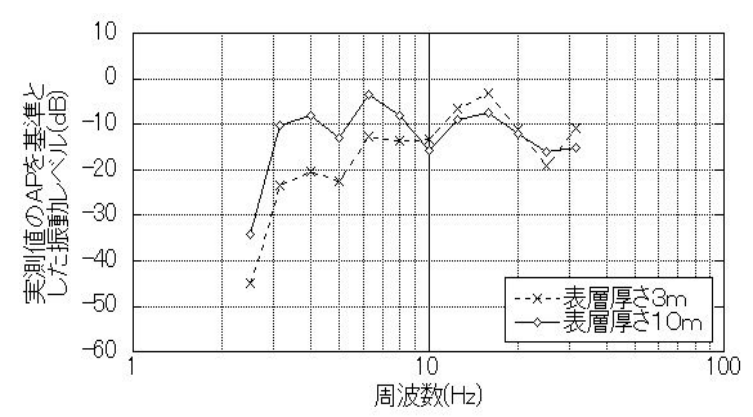

b ） $1 / 3$ オクターブバンド振動レベル

図-32 表層地盤の厚さが異なる場合の予測值の比較
体的に明かりフード設置時の方がやや小さいが，増加， 減少を繰り返す中で山の部分に着目すると, 構造物から $12 \mathrm{~m}$ 以内の近い距離では明かりフード設置時が $2 \mathrm{~dB}$ 程度 小さい一方，15m以上の遠い距離ではほとんど差がない． 周波数別では明かりフード設置時に加振源で卓越する $6.3 \mathrm{~Hz}$ のピークが目立つ一方，12.5Hzなど一部の周波数で はレベルが低くなっている，明かりフードの設置によっ て高架橋等の卓越振動モードが変化し, 加振源で卓越す る周波数との一致や相違の状況が異なってくることでレ ベル分布の状況が変化した可能性がある.

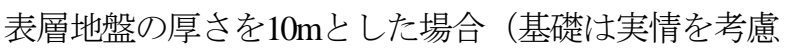
し杭基礎としている）の比較結果を図-32に示す. 構造 物中心から $15 \mathrm{~m}$ 以内では離れによって厚さ3mの予測值が 大きい場合と厚さ $10 \mathrm{~m} の$ 予測值が大きい場合の両方があ るものの, 離れが15m以上になるとほとんどの場合に厚 さ10mの予測值が大きくなり，その差はAPで概ね $22 \mathrm{~dB}$ 程 度である．軟弱で厚い表層地盤の場合に低い周波数の振 動レベルが増幅することは, 横山らのによる新幹線の実 測結果においても確認されており，営業線における予測 評価においては，考慮に入れるべき要素と考えられる.

\section{c) 新幹線勧告值と予測結果の比較考察}

前項において予測を行った各ケースの振動レベルにつ いて, 新幹線勧告值との比較をAPで行った結果を図-33 に示寸．A高架橋を対象としたのは，地盤の影響により 振動が増幅する傾向があるため, 振動レベルとしては安 全側の検討となるためである.

実測值は最大值と最小值の幅を示している，また，予 測值は図-29〜32に示寸通り, 構造物からの離れに従っ て増加・減少を周期的に繰返す中での最大值を示してい る. 条件を様々に変化させた場合で, 最大 $3 \mathrm{~dB}$ 程度予測 值に差が生じることが確認された．しかしながら，いず れのケースにおいても, 予測される振動レベルが新幹線 勧告值に対して十分に低い值となっており，営業線にお いてこれらの構造物や地盤条件が様々に組合せられた場 合を考えても, 新幹線の勧告值を達成することは十分に 可能であると考えられる.

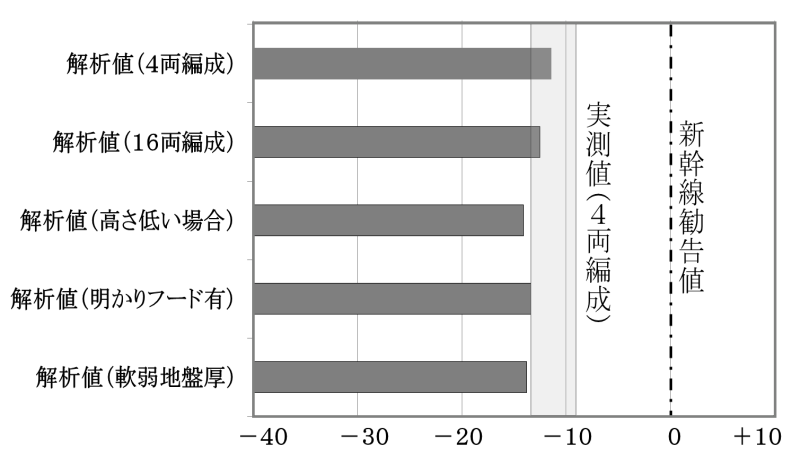

図-33 各ケースの予測結果と新幹線勧告值の比較 


\section{5. まとめ}

本論は，超高速鉄道の $500 \mathrm{~km} / \mathrm{h}$ 走行による沿線の地盤 振動現象を実験線の測定結果から解明し，解析モデルを 構築して営業線の諸条件における予測を行い，営業線の 環境保全目標值と想定される新幹線勧告值を十分に達成 できることを確認したものである，得られた主な成果は 以下の通りである.

1) 超高速鉄道について, 軌道部分では新幹線と同様, 台車間隔等の規則性に起因する周波数成分の振動が卓 越しているが，高架橋・橋梁や沿線地盤を伝達する過 程で大幅に振動が減衰する中, 固有振動数等, 構造物 の振動特性に起因する成分が卓越してくることが確認 された。

2) 超高速鉄道においても，地盤の条件によって沿線地 盤振動の伝達特性に違いがみられることがわかつた.

3）ボクセルモデルによる3次元動的FEM解析により，超 高速鉄道の構造物及び地盤の振動現象に見られる特徵 を反映し，沿線で観測される振動レベルの最大值を実 用上十分な精度で予測可能なことがわかった。

4) 営業線の種々の条件で振動レベルの予測を行った結 果, いずれの場合も新幹線勧告值に対して十分に小さ い值であり，勧告值の達成は十分可能であることが明 確になった.

しかしながら，解析モデルについては全体的な振動特 性を反映しているものの，1/3オクターブバンドの個々 の周波数レベルでは実測值との間に乘離が見られる部分 がある. そのため, 減衰条件の設定を適正化するなど, 精度向上に向けて更なる検討を進めていく必要がある. また必要な場合には, 固有振動数が車両による加振振動 数と一致しないような桁構造やスパン割りの選定等, 更 に積極的に振動を低減させるための設計・計画に対し, 本論で構築した解析モデルを活用していくための研究を 進めていくことも重要である.

\section{参考文献}

1) 超電導磁気浮上式鉄道実用技術評価委員会 : 超電導 磁気浮上式鉄道実用技術評価, 2009.

2) 後藤康之, 宮本雅章, 上野眞, 曽我部正道: 浮上式 鉄道における地盤振動特性について, 土木学会年次 講演会概要集第4部，55巻，pp.514-515， 2000.

3) 環境庁長官 : 環境保全上緊急を要する新幹線鉄道振 動対策について（勧告），環大特第32号，1971.

4) 吉岡修 : 新幹線鉄道振動の発生・伝播モデルとその 防振対策法への応用, 鉄道総研報告, 特別No.30, 268p., 1999.

5) 芦谷公稔, 吉岡修：高速走行時の地盤振動評価法, 鉄道総研報告, 8(6), pp.37-42, 1994.

6) 横山秀史, 芦谷公稔, 岩田直泰 : 新幹線高速走行時 の地盤振動特性と速度依存性評価, 鉄道総研報告, 20(1), pp.23-28, 2006.

7) 原恒雄, 吉岡修, 神田仁, 舟橋秀麿, 根岸裕, 藤野 陽三, 吉田一博 : 新幹線走行に伴う沿線地盤振動低 減のための高架橋補強工の開発, 土木学会論文集, No.766/I-68, pp.325-338, 2004.

8) 吉田幸司, 関雅樹：固有振動数に着目した鉄道高架 橋の健全度評価に関する研究，コンクリート工学年 次論文集，Vol.26，No.1，pp.1935-1940，2004.

9) 曽我部正道, 松本信之, 藤野陽三, 涌井一, 金森真, 宮本雅章：共振領域におけるコンクリート鉄道橋の 動的設計法に関する研究, 土木学会論文集, No.724/I-62, pp.83-102, 2003.

10) 吉岡修: 鉄道沿線の地盤振動, 第9回鉄道総研講演会 資料，pp.27-43，1996.

11) 吉岡修：等価起振力法による地盤振動の予測解析 : 鉄道総研報告，10(2)，pp.41-46， 1996.

12) 富田健司, 松浦章夫 : 浮上式鉄道構造物の設計に用 いる許容変位, 土木学会論文集, No.500/IV-25, pp.51-58, 1994.

13) 竹宮宏和, 前河隆太, 児嶋基成 : 高速列車下の軌道地盤系の2.5D-FEMによる振動予測と制振法の検討, 土木学会論文集, No.710/I-60, pp.247-255, 2002.

14) Hollister, S. J. and Kikuchi, N. : Homogenization Theory and Digital Imaging : A basis for studying the mechanics and design principles of bone tissue, Biotechnologies and Bioengineering, Vol.43, pp.586-596, 1994.

15）鈴木克幸：ボクセル解析とCAE：理研シンポジウム, ものつくり情報技術統合化研究プログラム, 第2回, 2002.

16) 櫻井英行, 白石知成 : 地下施設計画のための地下水 浸透流ボクセル解析，土木学会論文集，No.687/III-56, pp.155-168, 2001.

17) 秋山伸一, 池上泰史, アフニマル, 纐纐一起 : 大規 模3次元地下構造のモデル化と強震動シミュレーショ ン, 土木工学地震工学論文集, 11巻, pp.487-492, 2002.

(2011. 7. 18 受付) 


\section{FIELD MEASUREMENT RESULT AND FUTURE PREDICTION OF GROUND VIBRATION LEVELS ALONG THE ULTRA HIGH SPEED RAILWAY}

\section{Mamoru UNO, Takaaki NAGAOSA, Yozo FUJINO, Kimitoshi ASHIYA and Kazuhiko MORIKAWA}

This paper attempts to evaluate the characteristics of the ground vibration induced by ultra high speed trains moving on the current test line and to predict ground vibration levels along the projected routes under various conditions. First, the field vibration measurement by the use of the test line was carried out. Through the test results, it was indicated that the structural properties of girder bridges and surrounding ground have a great influence on the ground vibration along the test line in addition to the effects of periodic exciting force by the train. Next, numerical analysis models were constructed to simulate the traffic induced vibration problems. The 3-dimensional finite element method using voxel elements was employed in this paper in order to analyze the vibration model having a large number of degrees of freedom. Through the comparisons with the test results, it was confirmed that the employed numerical models gave fairly good results. Finally, it was shown by the present simulation analyses that the ground vibration levels along the ultra high speed railway would be much below the criteria used in the SHINKANSEN under several conditions considered in the projected routes. 